\title{
Erstatning, trygd og forsikring ved arbeidsuførhet
}

\author{
Kandidatnummer: 230 \\ Veileder: Asbjørn Kjønstad \\ Leveringsfrist: 25. november 2004
}

$(\mathrm{H}-04)$

Til sammen: 16.973 ord

20.11.2004 


\section{INNHOLDSFORTEGNELSE}

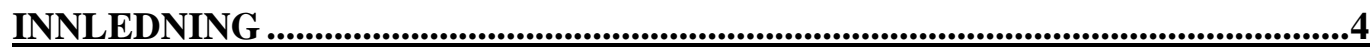

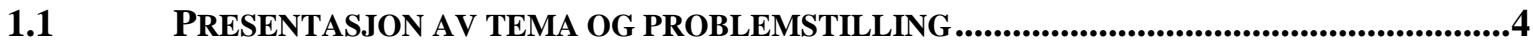

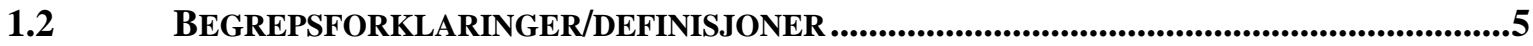

1.3 AVGRENSNINGER.............................................................................................................6

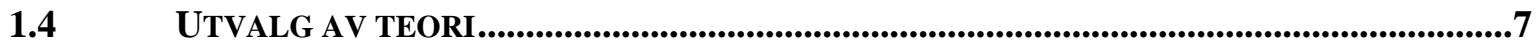

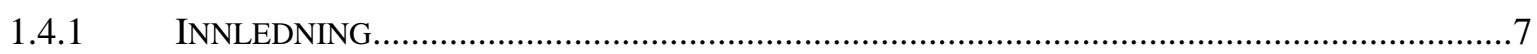

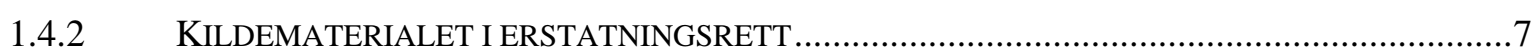

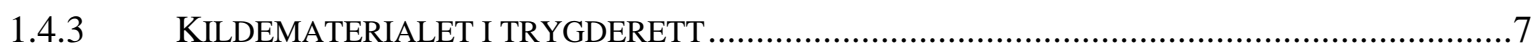

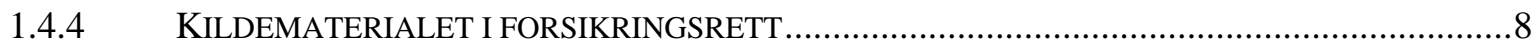

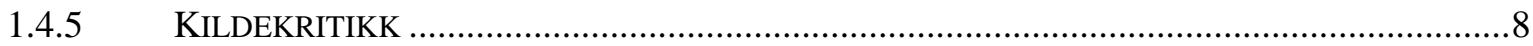

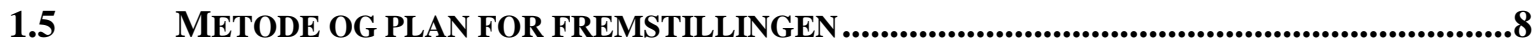

1.5.1 OVERSIKT OVER METODE OG FREMSTILLING …….........................................................

1.5.2 METODENS FORDELER OG BEGRENSNINGER .................................................................11

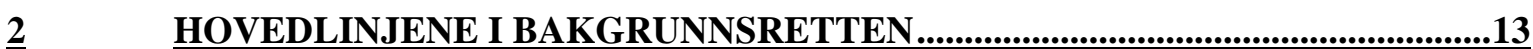

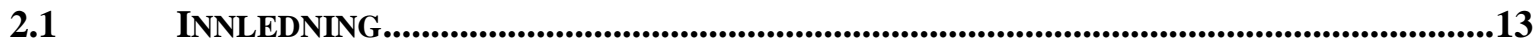

2.2 ERSTATNINGSRETT OG ARBEIDSUFØRHET ...............................................................14

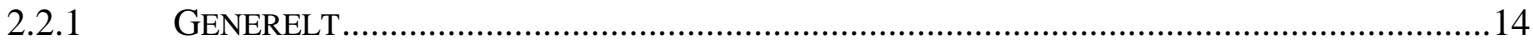

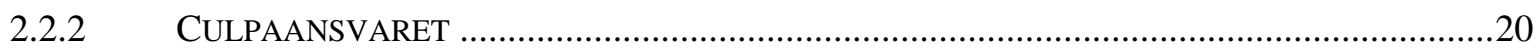

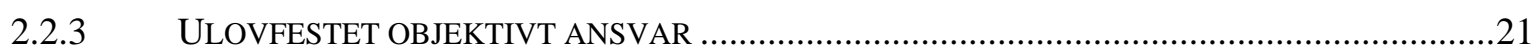

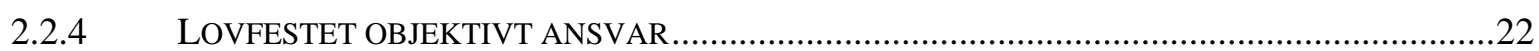

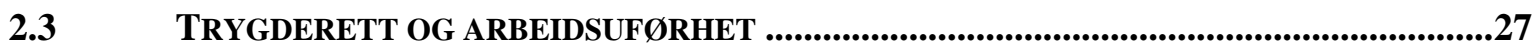

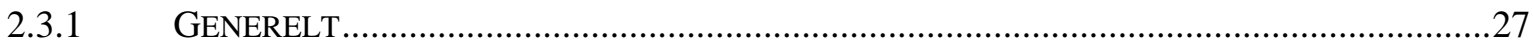

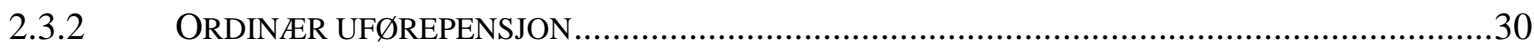

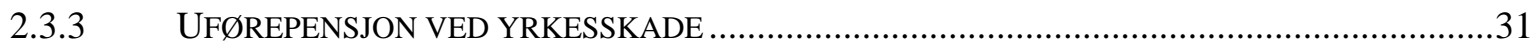

$2.4 \quad$ FORSIKRINGSRETT OG ARBEIDSUFØRHET.........................................................................33

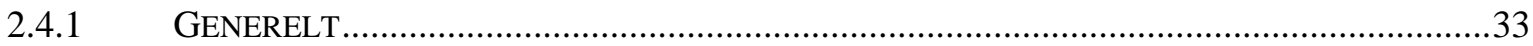

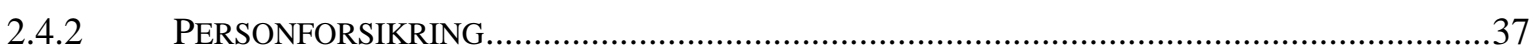

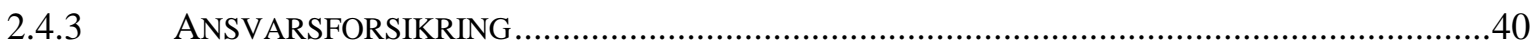

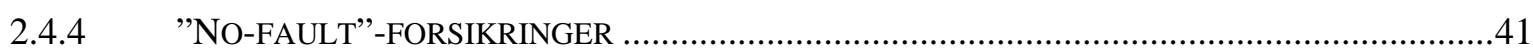


P.1 PROBLEMSTILLING OG DISPOSISJON ............................................................................

D.2 DET SITUASJONSORIENTERTE PERSPEKTIV ............................................................43

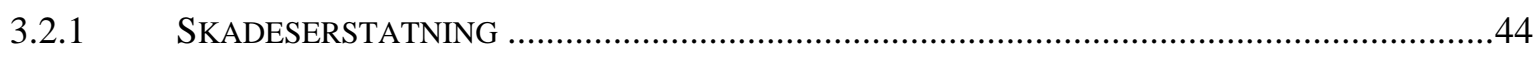

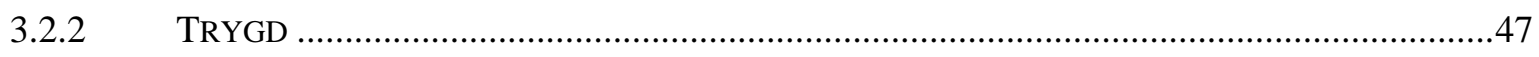

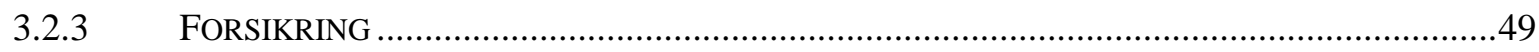

3.3 DET ANSVARSORIENTERTE PERSPEKTIV .....................................................................54

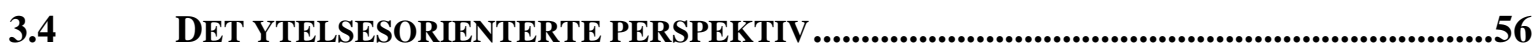

4 YTELSENES PÅVIRKNING AV ANDRE YTELSER OG ØVRIGE

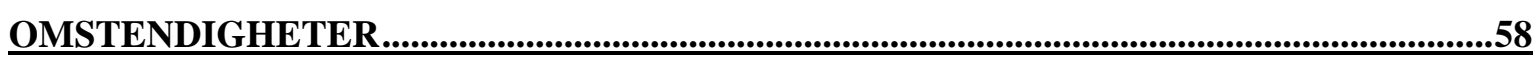

4.1 PROBLEMSTILLING OG DISPOSISJON …......................................................................58

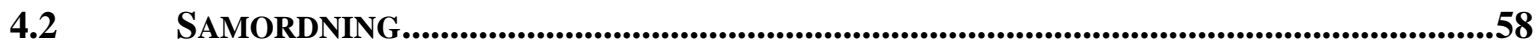

4.3 SКАTT.....................................................................................................................59

SIKKERHET FOR YTELSE....................................................................................................60

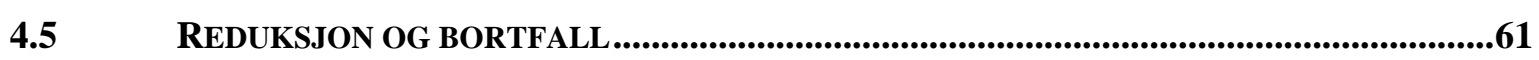

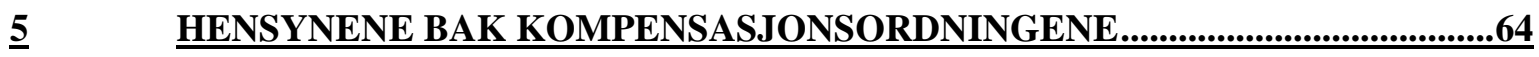

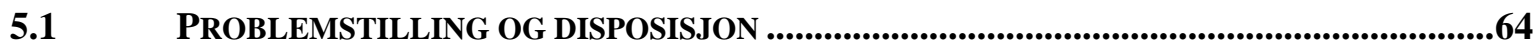

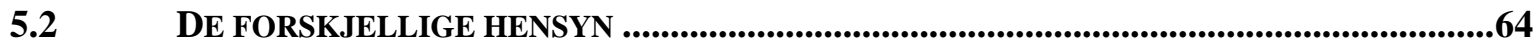

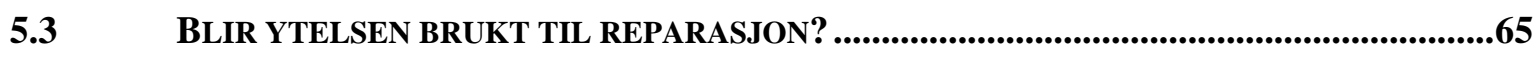

5.4 ER REGLENE EGNET TIL Å ”REPARERE” ARBEIDSUFØRHET I DAGENS SAMFUNN?....66

5.5 HAR REGLENE OM ERSTATNING VED ARBEIDSUFØRHET PREVENTIV VIRKNING?.....67

5.6 HVEM BETALER KOSTNADENE VED TAP SOM FØLGE AV ARBEIDSUFØRHET? ............68

5.7 ER DET MULIG Å OPPNÅ RETTFERDIGHET OG RIMELIGHET? ...................................69

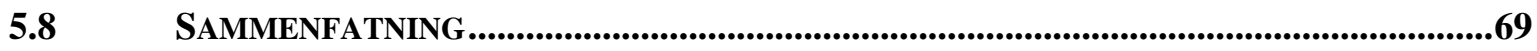

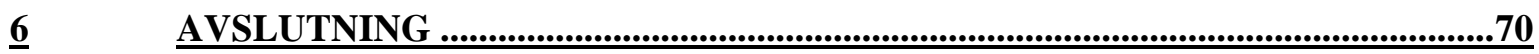

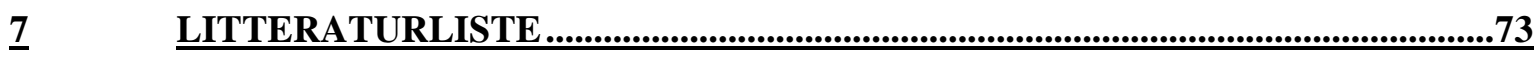




\section{INNLEDNING}

En av ti nordmenn i yrkesaktiv alder er varig arbeidsuføre i den forstand at de er innvilget uførepensjon i folketrygden. Andelen er stigende, og antallet nye uførepensjonister øker med ca. 7000 årlig. ${ }^{1}$ I tillegg kommer korttidsarbeidsuførhet. Av dette følger at store deler, kanskje flertallet, av den norske befolkning på en eller annen måte er berørt eller kommer til å bli berørt av problemstillinger på området.

\subsection{Presentasjon av tema og problemstilling}

Når en person blir arbeidsufør, faller fremtidig arbeidsinntekt bort. Vedkommende settes i utgangspunktet i en kritisk økonomisk situasjon. I tillegg til arbeidstaker selv, vil ektefelle, samboer, barn med flere, som blir forsørget av den uføre, bli direkte rammet. Videre vil ringvirkningene indirekte kunne påvirke omgivelser og samfunnet for øvrig. Mulighetene til å kompensere et slikt inntektsbortfall vil ha betydning for mange mennesker.

En finner grunnlag for kompensasjon for tap ved arbeidsuførhet innenfor flere rettsområder. Erstatningsretten, forsikringsretten og trygderetten har, blant sine formål, som oppgave å dekke et slikt tap. Kompensasjonsordningene som springer ut fra de forskjellig rettsområdene, varierer imidlertid i form og innhold. Reglene har likhetstrekk, men også forskjeller. Dette skaper liten oversikt. Selv om rettsområdene stort sett har samme formål, ser reglene ut til å gi forskjellig utslag avhengig av hvilket rettsområde man opptrer innenfor og hvilket livsområde den erstatningsbetingende hendelse har sin opprinnelse fra. Dette kan ha sin bakgrunn i at hensyn vektlegges ulikt mellom ytelsesgrunnlagene. I tillegg påvirkes ytelsenes størrelse av forskjellige omstendigheter. Dette er oppgavens tema.

Den enkelte som blir arbeidsufør, vil ofte ikke kjenne sin rettsstilling og ha problemer med å få gjennomslag for sine interesser. Dette har sammenheng med at feltet er komplisert og

\footnotetext{
${ }^{1}$ Trygdeetaten, Trygdeetatens årbok 2003, http://www.trygdeetaten.no
} 
uoversiktlig, og at den som skal yte, ofte oppfattes som uforholdsmessig sterk i forhold til den uføre. Den uføre vil derfor ofte ha behov for rådgivning. Følgelig er det viktig for meg og andre som kan komme bort i dette temaet som rådgivere, å ha oversikt over gjeldende rett. Oppgaven er et bidrag i den retning.

Hovedproblemstillingene som oppgaven søker å belyse er:

- Hvilke ytelser er aktuelle som kompensasjon for tap ved arbeidsuførhet?

- Hvor stor betydning har det for kompensasjon ved arbeidsuførhet hvilket livsområde uførheten har sin opprinnelse fra?

- Hvordan påvirkes den enkelte ytelse av evt. andre ytelser og øvrige omstendigheter?

- Hvilke hensyn bygger de forskjellige kompensasjonsytelser ved arbeidsuførhet på, og i hvor stor grad blir disse hensyn ivaretatt?

De aller fleste sider av temaet har tidligere vært belyst i litteraturen. Jeg kan likevel ikke se at denne oppgavens problemstillinger tidligere har vært behandlet i sammenheng og på den måten som jeg tar sikte på.

\subsection{Begrepsforklaringer/definisjoner}

\section{Arbeidsuførhet}

Uttrykket arbeidsuførhet benyttes ofte i oppgaven, og er i utgangspunktet noe vagt. I trygdesammenheng beskriver Kjønstad ${ }^{2}$ tilstanden som varig helsesvikt som setter en ute av stand til å skaffe seg inntekt ved eget arbeid. I forsikringssammenheng benyttes i utgangspunktet samme beskrivelse, men her må uførheten i tillegg ha varighet utover 2 år sammenhengende for kapitalforsikringer, og 3 eller 12 måneder for renteforsikringer. ${ }^{3}$ For å få en enhetlig beskrivelse vil jeg i denne sammenheng benytte følgende definisjon: Helt

\footnotetext{
${ }^{2}$ Asbjørn Kjønstad, Folketrygdens uførepensjon, Oslo 1997, s. 13-14.

${ }^{3}$ Norges Forsikringsforbund, Håndbok i forsikring, Oslo 1995 s. 128-130.
} 
eller delvis bortfalt evne til å utføre inntektsbringende arbeid. Det sees her bort fra forbigående arbeidsuførhet med varighet under to år, med unntak for uførerenter.

\section{Erstatning}

Begrepet erstatning har i dagligtalen et upresist innhold. Betydning varierer med sammenhengen begrepet blir benyttet i. Den naturlige språklige forståelsen som ligger i begrepet er en gjenoppretting som kommer i stedet for noe annet. ${ }^{4}$ Det er også slik jeg vil benytte det i denne oppgaven. Nærmere bestemt vil jeg bruke begrepet erstatning som en felles betegnelse på den økonomiske kompensasjon som måtte komme som følge av at arbeidsuførhet oppstår. Når jeg skal omtale ytelser fra de spesifikke rettsområdene erstatningsrett, trygderett og forsikringsrett benytter jeg hhv. skadeserstatning, trygdeytelser og forsikringsytelser.

\subsection{Avgrensninger}

\section{Avgrensning av tap}

Når jeg benytter begrepet tap, mener jeg tapet som følger av at arbeidsuførhet inntrer. Tapet oppstår ved at arbeidsinntekt bortfaller og er økonomisk målbart. I erstatningssammenheng møter man imidlertid stadig andre typer tap, og ofte skilles det ikke mellom disse. Jeg finner det derfor hensiktsmessig å foreta en avgrensning.

Jeg vil først avgrense mot økonomisk tap som ikke er en direkte følge av arbeidsuførheten. Et typisk eksempel på dette er fremtidige merutgifter. Slikt tap kan ha samme opprinnelse som arbeidsuførheten, men er ikke en følge av denne.

Videre vil jeg avgrense mot tap som ikke er av økonomisk karakter og derfor ikke målbart i penger. Dette kan for eksempel være tap av livsutfoldelse.

\footnotetext{
${ }^{4}$ Peter Lødrup, Lærebok i erstatningsrett, Oslo 1999 s. 31.
} 


\subsection{Utvalg av teori}

\subsubsection{Innledning}

Det finnes stort sett god tilgang på rettsvitenskapelig arbeid fra de tre rettsområder som her skal behandles. Det har derfor ikke vært nødvendig å utrede rettsområdene fra grunnen av. Et slikt arbeid ville vært meget arbeidskrevende, i tillegg til at det ligger utenfor denne avhandlings rammer. Utvalg av teori er derfor først og fremst gjort ut fra sekundært kildemateriell. Men også originalt forskningsmateriell anvendes i form av egenutviklede modeller.

Omfanget av sekundærkilder er generelt stort, men varierende. Det er gjort mest på erstatningsrettens, og minst på forsikringsrettens område. Dette gjelder både for generelle fremstillinger som tar for seg store deler av et rettsområde, og for annet forskningsmateriale som belyser avgrensede emner. For å finne frem til teori har jeg hovedsaklig foretatt søk i flere biblioteks beholdninger.

Siden tilgang på litteratur er god, har det ikke vært mulig å favne om alt. Utvalgsprosessen har ofte bestått i å velge mellom flere fremstillinger som tar for seg omtrent det samme. Valget er hovedsakelig gjort blant anerkjente forfattere. Fremstillingen er hele tiden forsøkt basert på minst to forskjellige arbeider.

\subsubsection{Kildematerialet i erstatningsrett}

Som kilder i erstatningsrett har jeg først og fremst benyttet materiell som behandler rettsområdet i sammenheng. Jeg har her valgt Lødrups ”Erstatningsrett” og Nygårds ”Skade og ansvar”. Dette er verk som, i tillegg til å omtale det enkelte grunnlag for erstatning, også omtaler erstatningsrettens bakgrunn og historie.

\subsubsection{Kildematerialet i trygderett}

For trygderettens del har jeg valgt flere verk av Kjønstad. ’Innføring i trygderett” er valgt som hovedlitteratur siden verket gir en god oversikt over trygderettens område. Jeg har også benyttet meg av "Trygd og erstatning ved personskade” som gir nyttige perspektiver på to av rettsområdene som her behandles. Videre er "Folketrygdens uførepensjon”, som 
gir en god oversikt over uførepensjonsordningen, valgt. I tillegg har jeg benyttet ”Yrkesskadetrygden”. De to siste er valgt siden de, etter min mening, gir den beste fremstillingen på sitt område.

\subsubsection{Kildematerialet i forsikringsrett}

Tilgjengelig kildemateriell på forsikringsrettens område er mindre omfattende enn på de andre to områdene. Jeg har valgt Selmers bok "Forsikringsrett” siden denne tar for seg en bred behandling av fagområdet. I tillegg har jeg supplert med "Hva er forsikring” fra Norges forsikringsforbund siden denne har en mer praktisk vinkling og plasserer forsikringsvirksomhet i en sammenheng.

\subsubsection{Kildekritikk}

På de fleste områder ville det vært mulig å velge alternativ litteratur. Jeg har imidlertid valgt de arbeider som jeg har antatt er best egnet til bruk i denne sammenheng. Det er en mulig feilkilde. Jeg tror likevel ikke dette vil ha nevneverdig innvirkning på mitt arbeid.

En del av det som er skrevet på disse områdene, er av forholdsvis gammel dato. Dette medfører en fare for at arbeidet baseres på foreldet materiale. Jeg har i slike tilfeller forsøkt å verifisere opplysninger med nyere rettskilder.

Ved å forholde seg til andres beskrivelse av bakgrunnsretten, slik jeg har gjort på mange områder, løper man generelt en risiko for at mangler ved materialets kvalitet påvirker resultatet. Selv om teoriutvalget er gjort med hensyn på best mulig kvalitet, er dette en mulig feilkilde. Jeg har likevel valgt denne fremgangsmåten fremfor det sterkt arbeidskrevende arbeidet med å undersøke rettskildene fra bunnen av.

\subsection{Metode og plan for fremstillingen}

\subsubsection{Oversikt over metode og fremstilling}

For å belyse oppgavens hovedproblemstillinger benyttes et deskriptivt forskningsdesign og arbeidet bygger i stor grad på kvalitativ analyse. 
Første skritt er å fremstille gjeldende rett på erstatnings-, trygde- og forsikringsrettens områder med betydning for kompensasjon ved arbeidsuførhet, jf. figur 1, trinn 1 . Dette gjøres i kapittel 2.

I tillegg til å være oppgavens teoretiske plattform, har denne delen funksjon som grunnlagsmateriale for den videre analyse. Denne delen av oppgaven baseres i stor grad på eksisterende forskning på rettsområdene.

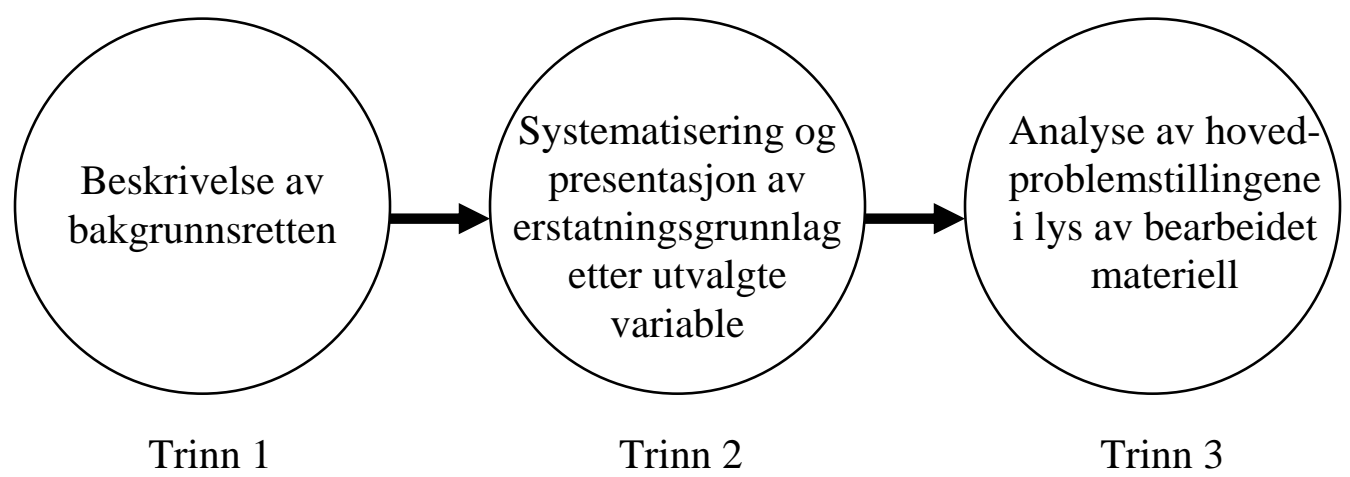

Figur 1: Beskrivelse av metode

Gjennom fremstillingen av bakgrunnsretten identifiseres erstatningsgrunnlag som har relevans i forhold til kompensasjon ved arbeidsuførhet. Dermed besvares den første hovedproblemstillingen.

For å gjøre grunnlagsmaterialet egnet til å belyse de øvrige hovedproblemstillingene blir dette bearbeidet slik at man får frem oversikt, sammenhenger, helheter og motsetninger. Dette gjøres ved å foreta et utvalg av systematiseringsvariabler som beskriver de forskjellige ytelsesgrunnlags egenskaper og karaktertrekk.

Nærmere bestemt består denne delen av prosessen i å systematisere og presentere de forskjellige kompensasjonsgrunnlag i forhold til utvalgte kriterier, jf. figur 1, trinn 2. Jeg har valgt ut 8 slike analysekriterier som beskrives i det følgende: 
1. Under betegnelsen erstatningsområde beskrives hvilke type-situasjoner som er omfattet av det enkelte grunnlag. Dette sier noe om betydningen av det livsområde uførheten har sitt utspring fra.

2. Av soliditetshensyn er det av interesse å få klarlagt hvem som skal betale erstatningen. Dette beskrives under systemeringsvariabelen ytelsespliktig.

3. Det er videre av interesse å få klarlagt hvilke kriterier som stilles for at det enkelte ansvarsgrunnlag foreligger. Dette presenteres under kriterier for ansvar.

4. Hvordan kompensasjonsytelsen beregnes, og hvilken form den utbetales i, fremstilles under utmåling / ytelsens karakter.

5. Under betegnelsen reduksjon / bortfall beskrives omstendigheter som kan føre til at erstatning helt eller delvis bortfaller eller opphører.

6. Det er ofte slik at forskjellige ytelser samordnes. Dette beskrives under punktet samordning.

7. Hvor stor sikkerhet den erstatningsberettigede har for et krav om erstatning kan få betydning. Dette beskrives under sikkerhet for ytelse.

8. Videre er erstatningsytelser underlagt forskjellige skatteregler. Dette beskrives under skatt.

Valget av systemeringskriterier er gjort for best mulig å kunne belyse oppgavens hovedproblemstillinger. Antall analysekriterier bør begrenses av hensyn til oversikten og den videre bearbeidelse. På den annen side må datagrunnlaget ikke bli for snevert, med den følge at beskrivelsen blir virkelighetsfjern. Her er antall kriterier begrenset til åtte, noe som antas å være tilstrekkelig for å ivareta begge hensyn.

Fremstillingen av bakgrunnsretten ledes frem til en tabellarisk oppsummering for hvert enkelt kompensasjonsgrunnlag. Også dette gjøres i kapittel 2. Her tilfredstilles ønsket om 
oversikt samtidig som materialet egner seg godt til videre sammenligninger, analyser og drøftelser.

På bakgrunn av den ovennevnte sammenfatning av grunnlagene for kompensasjon ved arbeidsuførhet, foretas deretter analyser og drøftelser med det formål å belyse de øvrige hovedproblemstillingene, jf. figur 1, trinn 3.

I kapittel 3 analyseres og drøftes betydningen av uførhetens opprinnelse for skadelidtes rett til erstatning. Den andre hovedproblemstillingen besvares her. Fremstillingen gjøres fra tre forskjellige perspektiver; et situasjonsorientert, et ansvarsorientert og et ytelsesorientert.

Fremstillingen i kapittel 4 tar for seg hvordan den enkelte ytelse påvirkes av evt. andre ytelser og øvrige omstendigheter. Den tredje hovedproblemstillingen søkes besvart her. Analysen og drøftelsen i dette kapittelet blir foretatt ut fra fire perspektiver; samordning, skatt, sikkerhet for ytelse og reduksjon/bortfall.

I kapitel 5 belyses avhandlingens fjerde hovedproblemstilling, som er hvilke hensyn de forskjellige kompensasjonsytelser ved arbeidsuførhet bygger på. Først presenteres ulike hensyn som ligger bak. Deretter drøftes forskjellige sider av hensynene.

I kapittel 6 foretas en sammenfatning. Her oppsummeres analysene og drøftelsene i de foregående kapitler.

\subsubsection{Metodens fordeler og begrensninger}

Beskrivelsen av de forskjellige grunnlag for ytelser etter bestemte variabler, gjør fremstillingen oversiktlig og håndterlig. Dette gjør materialet egnet til bruk i det videre arbeidet.

Som nevnt ovenfor, antallet analysekriterier er begrenset til 8. Dette er en mulig kilde til feil. Det kan her være fare for at enkelte av egenskapene ved det fenomen som analyseres ikke kommer frem. 
Flere variable ville gjort informasjonsinnholdet større, men samtidig mindre oversiktlig. Det må skapes balanse mellom oversikt på den ene siden og komplett informasjon på den andre. Valg av systematiseringens variable er følgelig kritisk for analyseverdien av fremstillingen. 


\section{Hovedlinjene i bakgrunnsretten}

\subsection{Innledning}

Det økonomiske tap som følge av arbeidsuførhet vil kunne utløse ett eller flere krav om kompensasjon. Adressat for kravet kan for det første være en ansvarlig skadevolder. For det andre er det mulig at kravet kan rettes mot folketrygden. For det tredje er det mulig at et forsikringsselskap vil være pliktig til å yte. Hvorvidt det er grunnlag for slike krav, og hvilke omstendigheter som påvirker erstatningens størrelse, blir behandlet i dette kapittel.

I det følgende fremstilles gjeldende rett innenfor hvert av de tre områdene erstatningsrett, trygderett og forsikringsrett. Innefor hvert rettsområde behandles mulige grunnlag for ytelser ved arbeidsuførhet og faktorer som påvirker disse ytelsene. Fremstillingen av rettsreglene leder frem til en tabellarisk sammenfatning for hvert grunnlag, som benyttes i det videre analysearbeidet.

For hvert av de tre rettsområdene vil jeg først ta for meg reglenes bakgrunn og utviklingstrekk, hensynene bak reglene, rettskildesituasjonen, samordning, skatt og sikkerhet for ytelser. Videre følger en generell fremstilling av grunnlag for ytelser og utmåling av slike ytelser. Deretter følger en presentasjon av det enkelte grunnlag for kompensasjon ved arbeidsuførhet. Etter hvert grunnlag oppsummeres fremstillingen tabellarisk.

Antallet grunnlag som kan gjøres gjeldende ved arbeidsuførhet varierer mellom rettsområdene. Jeg behandler 9 grunnlag med utspring i erstatningsretten, mens bare 2 grunnlag har sitt utspring fra trygderetten. I forsikringsretten behandler jeg 4 grunnlag utover de som også omtales i erstatningsretten. Omfanget av fremstillingen for hvert av rettsområdene vil derfor bære preg av dette.

Enkelte av grunnlagene for ytelser opptrer både innenfor erstatningsretten og innenfor forsikringsretten. Dette er hhv. bilansvaret, yrkesskadeansvaret, legemiddelansvaret og 
pasientskadeansvaret i erstatningsretten som samsvarer med hhv. trafikkforsikringen, yrkesskadeforsikringen, legemiddelforsikringen og pasientskadeerstatningen i forsikringsretten. Egentlig er dette to sider av samme sak. Jeg har likevel valgt å behandle grunnlagene fra begge disse vinkler. Dette er gjort for å få skape oversikt, og for å få frem sammenhengene best mulig.

\subsection{Erstatningsrett og arbeidsuførhet}

\subsubsection{Generelt}

\section{Opprinnelse og utvikling}

Erstatningsretten har vært gjenstand for stor utvikling gjennom tidene. I norrøn tid var erstatningsplikt nært knyttet til straff. ${ }^{5}$ Den skadelidte kunne kreve bot av gjerningsmannen. På denne måten fungerte boten som et påført onde for skadevolder og som en kompensasjon for skadelidte. Etter hvert skilte disse to rettsområder gradvis lag, og fra midten av 1800-tallet fremstod erstatningsretten som en selvstendig disiplin.

I begynnelsen av denne perioden var culparegelen rådende. Erstatningsplikt krevde altså at skadevolder kunne bebreides for sine skadevoldende handlinger. Samfunnsutviklingen førte imidlertid til stadig økt behov for objektive ansvarsregler, både av hensyn til skadelidte og samfunnet. ${ }^{6}$ Culparegelen strakk ikke lenger til.

Etter fremveksten av objektive ansvarsgrunnlag spør man ikke lenger bare om skaden er forvoldt ved uaktsom adferd, men også om hvem av partene som det er rimeligst at skal bære det oppståtte tap.

\section{Hovedhensyn bak erstatningsretten}

Det er vanlig å begrunne erstatningsreglene med et reparasjonsmotiv, et prevensjonsmotiv og et pulveriseringsmotiv. ${ }^{7}$

Prevensjonsmotivet har som funksjon å motvirke at det oppstår skade som medfører erstatningsbehov.

\footnotetext{
${ }^{5}$ Se f.eks Peter Lødrup, Lærebok i erstatningsrett, Oslo 1999 s. 33-34.

${ }^{6}$ Peter Lødrup, Lærebok i erstatningsrett, Oslo 1999 s. 34.

${ }^{7}$ Nils Nygaard, Skade og ansvar, Bergen 2000 s. 17-22.
} 
Pulveriseringsmotivet har som funksjon å fordele kostnaden ved skade på samfunnsøkonomisk best mulig måte, og vil bli nærmere omtalt i punkt 2.4.1.

Det som er av størst interesse i denne sammenhengen er reparasjonshensynet. Ved bortfall av arbeidsevne, og dermed også arbeidsinntekt fremtrer reparasjonsbehovet sterkt. Ut fra folks rettferdsforestillinger vil det være rimelig at den som uskyldig blir utsatt for et tap, får dette kompensert, samtidig som det er føles rettferdig at en uaktsom skadevolder blir påført det ondet som erstatningsplikt medfører. ${ }^{8}$ Her er det likevel kompensasjon for bortfalt arbeidsinntekt som er det primære.

\section{Rettskildesituasjonen}

Utviklingen av erstatningsretten var lenge overlatt til domstolene og juridisk teori, mens lovgiver spilte en beskjeden rolle. ${ }^{9}$ Fremdeles er erstatningsretten i stor grad basert på sedvane, ulovfestede rettsgrunnsetninger og rettspraksis.

I de siste tiår har lovgivers aktivitet på erstatningsrettens område tatt seg opp. Den mest sentrale loven er skadeserstatningsloven av 13. juni 1969 nr. 26 som i stor grad er en kodifisering og videreutvikling av tidligere gjeldende rett, utviklet gjennom rettspraksis og rettsteori. ${ }^{10}$ I tillegg kommer en rekke bestemmelser som er spredt rundt i lovgivningen. De sistenevnte reglene er normalt utformet med sikte på spesielle virksomheter eller spesielle typer skadeforvoldelser.

\section{Samordning}

De totale ytelser, fra alle erstatningsordninger, kan noen ganger gi uforholdsmessig store ytelser. Det er derfor innført enkelte regler som reduserer ytelsesplikten. Det grunnleggende prinsipp er at det er netto-tapet som skal erstattes. ${ }^{11}$

På erstatningsrettens område skal man gjøre fradrag for trygdeytelser. Dette følger av skadeserstatningsloven § 3-1 (3) første punktum. Dette vil imidlertid som hovedregel bare være aktuelt for trygdeytelser som tar sikte på å dekke samme formål som vedkommende

\footnotetext{
${ }^{8}$ Nils Nygaard, Skade og ansvar, Bergen 2000 s. 19.

${ }^{9}$ Peter Lødrup, Lærebok i erstatningsrett, Oslo 1999 s. 34-35.

${ }^{10}$ Peter Lødrup, Lærebok i erstatningsrett, Oslo 1999 s. 36.
} 
erstatningspost. ${ }^{12}$ Av samme bestemmelse følger videre at man også skal ta hensyn til forsikringsytelser som skadevolder har betalt premien for og forsikringer i arbeidsforhold, herunder kollektive pensjonsytelser.

Forsikringsytelser som den skadelidte selv betaler premie for må man derimot ikke ta hensyn til, jf. § 3-1 (3) annet punktum. Grunnen til at denne type forsikringsytelser behandles annerledes, er for det første at er det urimelige i at ytelsen skal komme skadevolder til gode. For det andre bør den som ønsker - og betaler for - en særlig trygghet, ha krav på å beholde den. ${ }^{13}$

\section{Skadeserstatning og skatt}

For skadeserstatningens del varierer skattebehandlingen mellom de forskjellige ytelsestyper. Erstatning for lidt inntektstap er skattepliktig på samme måte som den bortfalte inntekt ville ha vært. ${ }^{14}$ Ytelsen beskattes som personinntekt, herunder gjelder mellomhøy sats for pensjonsavgift, som er 7,8 prosent. ${ }^{15}$ Disse ytelsene fastsettes etter bruttometoden, som tar utgangspunkt i skadelidtes årlige tap før skatt. ${ }^{16}$

Posten tap av fremtidig erverv kan utbetales terminvis eller som engangsbeløp. Terminvise utbetalinger vil være skattepliktige på ytelsestidspunktet, i motsetning til engangsbeløp som ikke er det. ${ }^{17}$ Ytelsene fastesettes etter et nettometoden. Dette innebærer å beregne tapet på grunnlag av netto årstap. ${ }^{18}$

Generelt for alle ytelsestypene, også trygde- og forsikringsytelser, er det slik at utbetalte beløp blir gjenstand for formuesbeskatning, jf. skatteloven § 4-1 (1) og avkastningsbeskatning, jf. skatteloven § 5-20 (1) b. ${ }^{19}$ Skattesatsene vil avhenge av hvordan midlene er plassert. Dette er momenter som hensyntas ved utmåling av skadeserstatning.

\footnotetext{
${ }^{11}$ Peter Lødrup, Erstatningsberegningen ved personskader, Oslo 1983 s. 44.

${ }^{12}$ Asbjørn Kjønstad, Erstatningsretten i utvikling, Oslo 2003 s. 96-97.

${ }^{13}$ Peter Lødrup, Erstatningsberegningen ved personskader, Oslo 1983 s. 47.

${ }^{14}$ Frederik Zimmer, Lærebok i skatterett, 3. utg., Oslo 1997 s. 143-146.

${ }_{15}^{15}$ Finansdepartementet, Skattesatser og beløpsgrenser mv. for 2003 og 2004, www.odin.no/fin

${ }^{16}$ Peter Lødrup, Lærebok i erstatningsrett, Oslo 1999 s. 449.

${ }^{17}$ Peter Lødrup, Lærebok i erstatningsrett, Oslo 1999 s. 442.

${ }^{18}$ Peter Lødrup, Erstatningsberegningen ved personskader, Oslo 1983 s. 50-51.

${ }^{19}$ Nils Nygaard, Skade og ansvar, Bergen 2000 s. 112.
} 


\section{Sikkerhet for ytelser}

Når et grunnlag for skadeserstatning foreligger, utløses det et krav mot den som etter grunnlaget skal yte. Siden erstatning utmåles i penger, dreier det seg her om et pengekrav som følger reglene i pengekravsretten. ${ }^{20}$ For at den erstatningsberettigede, som får stilling som kreditor, er det ikke nok å få fastslått at et slikt krav er til og hvor stort det er. For at erstatningsberettigede skal kunne nyttiggjøre seg av sin rettighet, må verdien overføres. Dette er imidlertid betinget av at erstatningsyteren, debitor, er betalingsdyktig eller kan stille betryggende sikkerhet for ytelsen.

Dersom kravet har sitt utspring i reglene om skadeserstatning, er det skadevolders økonomiske situasjon, enten det er en privatperson eller en virksomhet, som avgjør om kravet kan innfris. Hvis den erstatningsansvarlige er ute av stand til å gjøre opp for seg, er det lite hjelp i at kravet er konstatert og evt. kan tvangsinndrives.

Verdien av en rett til erstatning er altså avhengig av skadevolders økonomiske situasjon. Jo større kravet er, jo mindre er muligheten for at skyldneren kan gjøre opp for seg. Fra den skadelidtes side vil det fremstå som noe tilfeldig om den som er ansvarlig for skaden, er betalingsdyktig eller ikke. Dette er i seg selv en klar oppfordring til å etablere private forsikringsordninger på eget liv og helse.

Noen ganger vil flere være ansvarlige for en skade i fellesskap. I slike tilfeller fastsetter skadeserstatningsloven § 5-3 at de ansvarlige hefter solidarisk for erstatningsbeløpet. Skadelidte kan i slike tilfeller velge å inndrive kravet fullt ut hos en av de ansvarlige eller ved delbetaling fra hver av de ansvarlige. ${ }^{21}$ Dette gjør at sjansen for å få erstatning øker.

Det vil i mange situasjoner foreligge en ansvarsforsikring som kan tre i stedet for skadevolders manglende erstatningsevne. Skadevolders økonomiske evne vil her være uten betydning. I slike tilfeller kan skadelidte rette sitt krav direkte mot forsikringsselskapet, jf. forsikringsavtaleloven $\S \S 7-6$ og 7-7. Det vil da være forsikringsselskapet eller forsikringsfellesskapets betalingsdyktighet som avgjør om erstatningen kan utbetales. Dette kommer jeg nærmere inn på i punkt 2.4.1.

\footnotetext{
${ }^{20}$ Trygve Bergsåker, Lærebok i pengekravsrett, Oslo 1996 s. 15.

${ }^{21}$ Nils Nygaard, Skade og ansvar, Bergen 2000 s. 398-399.
} 


\section{Grunnlag for skadeserstatning}

For at erstatningsansvar eller erstatningsplikt skal være tilstede, må flere vilkår være oppfylt. For det første må det i utgangspunktet foreligge et økonomisk tap eller varig og betydelig men. Dertil må det foreligge ansvarsgrunnlag. Videre må det foreligge årsaksammenheng, altså et minimum av forbindelse mellom ansvarsgrunnlag og skade. Videre må denne forbindelsen mellom ansvarsgrunnlag og skade være tilstrekkelig påregnelig. $^{22}$

I det følgende er det ansvarsgrunnlaget som skal stå i fokus. Hvorvidt de øvrige betingelser er oppfylt, er vurderinger som ligger utenfor denne oppgavens rammer.

Det er vanlig å dele ansvarsgrunnlag i to hovedformer, culpaansvaret og ansvar på objektivt grunnlag. ${ }^{23}$ Det eksisterer ikke noen klar grense mellom disse to ansvarsformer, men det er til dels ulike aspekter som vektlegges ved de to ansvarsgrunnlag. Jeg vil likevel benytte denne hovedinndelingen.

En modell som enkelt beskriver sammenhengen mellom ethvert tilfelle av arbeidsuførhet og skadeserstatningsansvar, er vist i figur 2.

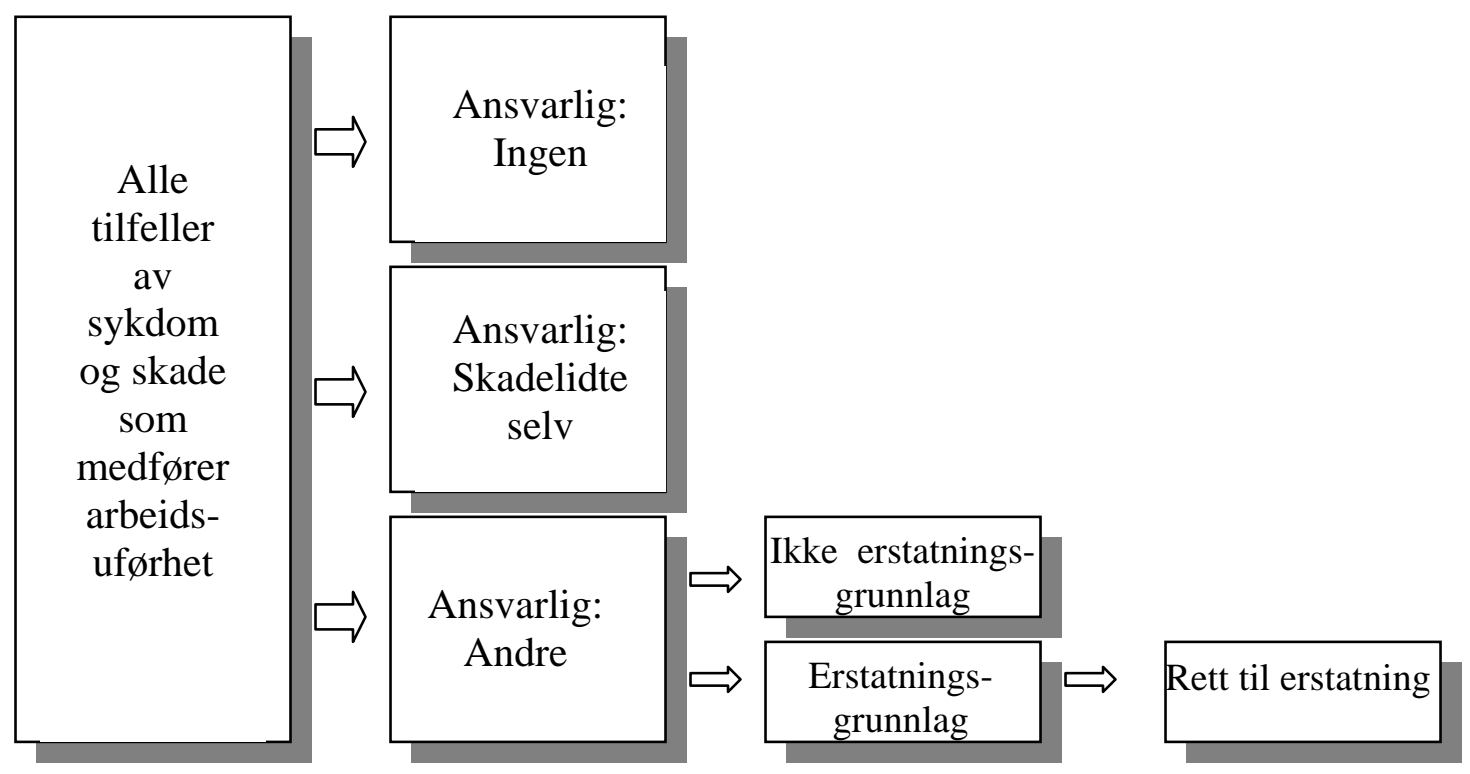

Figur 2: Sammenhengen mellom skade- og sykdomstilfeller og grunnlag for skadeserstatning

${ }^{22}$ Dette skriver blant andre Peter Lødrup, Lærebok i erstatningsrett, Oslo 1999 s. 58-62.

${ }^{23}$ Peter Lødrup, Lærebok i erstatningsrett, Oslo 1999 s. 59. 
Figuren tar utgangspunkt i alle tilfeller av sykdom og skade som fører til arbeidsuførhet. For at disse hendelser skal medføre erstatningsplikt etter skadeserstatningsretten, må det finnes en eller flere ansvarlige skadevoldere. Man kan altså se bort fra sammenhenger hvor det ikke finnes noen ansvarlig skadevolder. Man kan også se bort fra situasjoner hvor skadelidte selv er ansvarlig. Dette er likevel ikke tilstrekkelig for å kunne konstatere erstatningsansvar. Den skadevoldende handling må i tillegg være av en slik karakter at den faller inn under reglene som hjemler erstatningsansvaret. Som vi ser av figuren, er det bare en liten del av mulige skadetilfeller som gir grunnlag for skadeserstatning.

\section{Utmåling av skadeserstatning}

Når ansvaret er konstatert, er neste skritt å avklare hvor stort erstatning skadelidte skal få. Utgangspunktet er at erstatningen skal tilsvare tapet, altså full erstatning, se skadeserstatningsloven § 3-1. Prinsippet for erstatningsutmålingen vil da være at differansen mellom skadelidtes økonomiske situasjon uten skaden og situasjon med skaden skal kompenseres. Her hensyntas, ikke bare tapspostene men også de reduserte utgifter skaden har medført. ${ }^{24}$

Tapspostene som inngår i erstatningsberegningen etter personskade, er tapt inntekt, tap i fremtidig inntekt, påførte utgifter og fremtidige utgifter. ${ }^{25}$ Erstatningen beregnes som hovedregel som en engangssum. I visse tilfeller finnes det regler som standardiserer erstatningsutmålingen. Erstatning til barn og erstatning for yrkesskade er eksempler på slike.

Erstatningsbeløpet kan i noen sammenhenger bli redusert, og kan til og med falle helt bort. Skadeserstatningsloven inneholder generelle regler om lempning og medvirkning.

Lempningsreglene er innført for å unngå at erstatningsutmålingen skal bli urimelig tyngende for skadevolder. ${ }^{26}$ Den generelle lempningsregel finnes i skadeserstatningsloven $\S 5$-2, men det finnes også enkelte regler i spesiallovene. Momenter som kan vektlegges, er

\footnotetext{
${ }^{24}$ Peter Lødrup, Lærebok i erstatningsrett, Oslo 1999 s. 446-450.

${ }^{25}$ Se skadeserstatningsloven § 3-1(1).

${ }^{26}$ Kåre Lilleholt, Knophs oversikt over Norges rett 11. utg, Oslo 1998 s. 477.
} 
om ansvaret virker urimelig tyngende for skadevolder, og om omstendighetene tilsier at skadelidte bør bære deler av tapet selv.

Også medvirkning kan med føre at erstatningen settes ned eller faller bort. Momenter som vektlegges er om det er rimelig med hensyn til adferden, omfanget av skaden og forholdene forøvrig. Dette følger av skadeserstatningsloven § 5-1.

Nært opp til medvirkningsreglene ligger læren om aksept av risiko. Hvis skadelidte kan anses for å ha akseptert den risiko som handlingens skadevoldende evne representerer, vil vedkommende selv måtte bære tapet. Jeg kommer tilbake til dette i avsnitt 4.5.

\subsubsection{Culpaansvaret}

Ansvar på subjektivt grunnlag er ansvar for konsekvenser som er voldt ved en handling eller en unnlatelse som er uaktsom eller uforsvarlig. ${ }^{27}$ Culpaansvaret er utgangspunktet og hovedregelen. Hovedregelen at den som handler uaktsomt eller uforsvarlig, er erstatningsansvarlig overfor skadelidte for den skade han måtte forårsake. Skyld er altså en betingelse for erstatningsansvar etter denne regelen.

Culpaansvaret kan igjen deles inn i tre grader av skyld; simpel uaktsomhet, grov uaktsomhet og forsett. I denne sammenhengen er det skillet nedover mellom simpel uaktsomhet og skyldfri handling som er av størst interesse, men enkelte ganger er det nødvendig og trekke skillet mellom simpel uaktsomhet og grov uaktsomhet. Vurderingen skjer med utgangspunkt i sannsynligheten for skade, størrelsen av en eventuell skade og skadevolderens handlingsalternativer. ${ }^{28}$ Det foretas med andre ord en helhetsvurdering av om skadevolder forutså eller burde forutse risikoen for at skade kunne inntre.

Culpaansvaret er hjemlet i både lovfestet og ulovfestet rett. Som nevnt er det en alminnelig ulovfestet regel i vårt rettssystem at erstatningsansvar oppstår ved skade som følger av uaktsom eller uforsvarlig opptreden. Regelen, som bærer preg av å være en allmenn rettsgrunnsetning, gjelder dersom ikke andre regler medfører noe annet. Culparegelen er en

\footnotetext{
${ }^{27}$ Peter Lødrup, Lærebok i erstatningsrett, Oslo 1999 s. 122-123.

${ }^{28}$ Peter Lødrup, Lærebok i erstatningsrett, Oslo 1999 s. 130-150.
} 
forsvarlighetsstandard eller en uaktsomhetsnorm. Det er først og fremst rettspraksis som vil være rettesnor for regelens nærmere innhold. ${ }^{29}$

Noen ganger er culparegelen lovfestet. Rundt om i lovverket finner vi regler som pålegger erstatningsansvar på grunnlag av uaktsom handlemåte. Et eksempel på dette er sjøloven av 24. juni 1994 nr. 39, del 3. I lovgivningen benyttes gjerne begreper som "uaktsomhet” eller "feil og forsømmelse" i slike sammenhenger.

Ved å lovregulere erstatningsansvar etter culpanormen har lovgiver mulighet til å pålegge erstatningsansvar på områder som ellers ikke ville være omfattet av det ulovfestede culpaansvaret. Samtidig gir det en viss mulighet til å stille andre krav til aktsomhetsstandarden enn det som følger av den ulovfestede forsvarlighetsstandarden.

I begge tilfeller, både når det gjelder culpanormen på ulovfestet grunnlag og når ansvaret er lovfestet, må det i den enkelte sak tas foretas en vurdering av om det er utvist erstatningsbetingende uaktsomhet. I begge tilfeller må man falle tilbake på generelle, culparettslige betraktninger. $^{30}$

Culpaansvaret kan oppsummeres på følgende måte:

\begin{tabular}{|l|l|}
\hline Systematiseringskriterier & Beskrivelse \\
\hline Erstatningsområde & Alle \\
\hline Ytelsespliktig & Ansvarlig skadevolder \\
\hline Kriterier for ansvar & Skyld (minst uaktsomhet), årsaksammenheng \\
\hline Utmåling / ytelsens karakter & Tapt inntekt, tap i fremtidig inntekt / engangsytelse \\
\hline Reduksjon, bortfall & Medvirkning jf. skl § 5-1 og lempning jf. skl § 5-2 \\
\hline Samordning & Med andre erstatnings-, trygde- og forsikringsytelser \\
\hline Sikkerhet for ytelse & Skadevolders betalingsevne, evt. ansvarsforsikring \\
\hline Skatt & Skatt på tapt inntekt, ikke skatt på tapt fremtidig inntekt \\
\hline
\end{tabular}

\subsubsection{Ulovfestet objektivt ansvar}

Ansvarsgrunnlag kan foreligge selv om skyld ikke er tilstede. Grunnlaget er da objektivt. Dette er den andre hovedgruppen av ansvarsgrunnlag i erstatningsretten. Også det objektive ansvaret er dels lovfestet og dels ulovfestet. ${ }^{31}$

\footnotetext{
${ }^{29}$ Se bl.a. Nils Nygaard, Skade og ansvar, Bergen 2000 s. 170-172.

${ }^{30}$ Peter Lødrup, Lærebok i erstatningsrett, Oslo 1999 s. 125.

${ }^{31}$ Peter Lødrup, Lærebok i erstatningsrett, Oslo 1999 s. 195.
} 
Det ulovfestede objektive erstatningsansvaret har utviklet seg gjennom rettspraksis de siste århundrene parallelt med samfunnsutviklingen som en konsekvens av at skyldansvaret ikke strakk til. Spesielt gjorde den industrielle utvikling det ønskelig med ordninger som påla ansvar for påført skade selv om ingen skyld forelå. ${ }^{32}$ Dette innebærer å plassere byrden der hvor det oppfattes som mest rimelig at den plasseres, både av hensyn til den skadelidte og til samfunnet for øvrig.

Det ulovfestede objektive ansvaret kan oppsummeres slik:

\begin{tabular}{|l|l|}
\hline Systematiseringskriterier & Beskrivelse \\
\hline Erstatningsområde & Alle \\
\hline Ytelsespliktig & Ansvarlig skadevolder \\
\hline Kriterier for ansvar & Skadevolder er ”nærmest” til å bære tap, årsaksammenheng \\
\hline Utmåling / ytelsens karakter & Tapt inntekt, tap i fremtidig inntekt / engangsytelse \\
\hline Reduksjon/bortfall & Medvirkning jf. skl § 5-1 og lempning jf. skl § 5-2 \\
\hline Samordning & Med andre erstatnings-, trygde- og forsikringsytelser \\
\hline Sikkerhet for ytelse & Skadevolders betalingsevne, evt. ansvarsforsikring \\
\hline Skatt & Skatt på tapt inntekt, ikke skatt på tapt fremtidig inntekt \\
\hline
\end{tabular}

\subsubsection{Lovfestet objektivt ansvar}

De lovfestede objektive ansvarsgrunnlagene er innført på en rekke livsområder. Dette skyldes for det første at det er ønskelig med et objektivt ansvar på et område som ikke er omfattet av det ulovfestede objektive ansvaret. ${ }^{33}$ For det andre kan det skyldes at lovgiver ønsker å markere at det ikke skal være tvil om ansvarsgrunnlaget.

Denne ansvarstypen kombineres gjerne med forsikringsplikt eller i det minste en oppfordring til å etablere ansvarsdekninger. De viktigste lovfestede objektive ansvarsgrunnlagene gjennomgås nedenfor. De forskjellige grunnlags egenskaper kommenteres i den grad de avviker fra det ulovfestede objektive ansvaret som er behandlet ovenfor.

\section{Bilansvaret}

Bilansvarsloven av 3. februar 1961 hjemler bilansvaret som pålegger objektivt ansvar for skade som skyldes motorvogn. Bakgrunnen er at motorvogn antas og ha høy skaderisiko.

\footnotetext{
32 Peter Lødrup, Lærebok i erstatningsrett, Oslo 1999 s. 147-151.

33 Peter Lødrup, Lærebok i erstatningsrett, Oslo 1999 s. 195.
} 
Ansvaret er kombinert med forsikringsplikt slik at det er motorvognens forsikringsselskap som hefter på objektivt grunnlag. ${ }^{34}$ Skadelidte får altså er direkte krav mot motorvognens forsikringsselskap. Dersom motorvognen er ukjent eller uforsikret dekkes ansvaret av forsikringsselskapene i fellesskap. ${ }^{35}$ Ansvaret er meget omfattende og dekker også skade på fører.

Bilansvarsloven har i § 7 regler om skadelidtes medvirkning. Erstatningen kan reduseres eller falle helt bort dersom skadelidte har medvirket forsettelig eller uaktsomt. Dette gjelder likevel ikke dersom skadelidte bare kan legges lite til last. Her stilles skadelidte bedre enn det som følger av den generelle regel i skadeserstatningsloven.

Fremstilt etter systematiseringsvariablene blir bilansvaret som følger:

\begin{tabular}{|l|l|}
\hline Systematiseringskriterier & Beskrivelse \\
\hline Erstatningsområde & Skade som motorvogn gjør \\
\hline Ytelsespliktig & Motorvognens trafikkforsikringsselskap, evt. forsikringsselskap i felleskap \\
\hline Kriterier for ansvar & Skade forårsaket av motorvognen \\
\hline Utmåling / ytelsens karakter & Tapt inntekt, tap i fremtidig inntekt / engangsytelse \\
\hline Reduksjon / bortfall & Medvirkning, unntatt ved ’lite til last”, jf. bal § 7 og lempning jf. skl § 5-2 \\
\hline Samordning & Med andre erstatnings-, trygde- og forsikringsytelser \\
\hline Sikkerhet for ytelse & Trafikkforsikringsselskaps betalingsevne \\
\hline Skatt & Skatt på tapt inntekt, ikke skatt på tapt fremtidig inntekt \\
\hline
\end{tabular}

\section{Produktansvaret}

Produktansvaret følger av produktansvarsloven av 23. desember 1988 nr. 104.

Ansvarsgrunnlaget er skade som følge av sikkerhetsmangel. Sikkerhetsmangel innebærer at produktet ikke byr på den sikkerhet som man med rimelighet kan vente. ${ }^{36}$

Før produktansvarslovens tid var det de alminnelige erstatningsrettslige reglene som fikk anvendelse på produktskadene. Slik vil det fremdeles være dersom det stiller skadelidte bedre enn hva som følger av produktansvaret. ${ }^{37}$

Det finnes ingen obligatorisk forsikringsplikt eller pool-ordninger som sikrer skadelidte i henhold til produktansvaret. Om en pliktig erstatningsytelse kommer til utbetaling vil

\footnotetext{
${ }^{34}$ Ole Andresen, Bilansvaret, Oslo 1990 s. 13.

${ }^{35}$ Se bilansvarsloven $\S 4$.

${ }^{36}$ Jf. produktansvarsloven §2-1 (1).

${ }^{37}$ Peter Lødrup, Lærebok i erstatningsrett, Oslo 1999 s. 219-232.
} 
følgelig avhenge av skadevolders betalingsevne eller om skadevolder frivillig har etablert ansvarsforsikring.

Produktansvaret kan oppsummeres som følger:

\begin{tabular}{|l|l|}
\hline Systematiseringskriterier & Beskrivelse \\
\hline Erstatningsområde & Skade forårsaket av et produkts sikkerhetsmangel \\
\hline Ytelsespliktig & Produsent, importør el. \\
\hline Kriterier for ansvar & Skade voldt av produkt, sikkerhetsmangel \\
\hline Utmåling / ytelsens karakter & Tapt inntekt, tap i fremtidig inntekt / engangsytelse \\
\hline Reduksjon/bortfall & Medvirkning jf. skl § 5-1 og lempning jf. skl § 5-2 \\
\hline Samordning & Med andre erstatnings-, trygde- og forsikringsytelser \\
\hline Sikkerhet for ytelse & Produsentens betalingsevne, evt. ansvarsforsikring \\
\hline Skatt & Skatt på tapt inntekt, ikke skatt på tapt fremtidig inntekt \\
\hline
\end{tabular}

\section{Legemiddelansvaret}

Legemiddelansvaret følger også av produktansvarsloven. Dette ansvarsgrunnlaget er underlagt egne bestemmelser som følge av spesielt stort skadepotensiale. Dette kan f.eks være bivirkninger. Ansvaret er objektivt, og pålegger produsenter og importører forsikringsplikt. Legemiddelansvaret er bygget opp etter samme lest som bilansvaret. Skadelidte kan derfor rette sitt krav mot legemiddelforsikringen, som også dekker skade voldt av ukjent eller uforsikret legemiddel. ${ }^{38}$

Legemiddelansvaret fremstilt etter de utvalgte variabler:

\begin{tabular}{|l|l|}
\hline Systematiseringskriterier & Beskrivelse \\
\hline Erstatningsområde & Følge av et legemiddels skadevoldende egenskaper \\
\hline Ytelsespliktig & Legemiddelforsikringen \\
\hline Kriterier for ansvar & Skade voldt av legemiddel \\
\hline Utmåling / ytelsens karakter & Tapt inntekt, tap i fremtidig inntekt / engangsytelse \\
\hline Reduksjon/bortfall & Medvirkning jf. skl § 5-1 og lempning jf. skl § 5-2 \\
\hline Samordning & Med andre erstatnings-, trygde- og forsikringsytelser \\
\hline Sikkerhet for ytelse & Legemiddelforsikringens betalingsevne \\
\hline Skatt & Skatt på tapt inntekt, ikke skatt på tapt fremtidig inntekt \\
\hline
\end{tabular}

\section{Pasientskadeansvaret}

Pasientskadeansvaret, som følger av pasientskadeloven av 15. juni 2001 nr. 53, gir som hovedregel objektivt erstatningsansvar for skade som følge av behandling ved helseinstitusjoner. Krav som følge av skade under behandling av offentlig helsetjeneste skal rettes mot Norsk Pasientskadeerstatning, jf. § 6. Utenfor den offentlige helsetjeneste er

${ }^{38}$ Peter Lødrup, Lærebok i erstatningsrett, Oslo 1999 s. 233-235. 
det forsikringsplikt. Her skal krav rettes direkte mot forsikringsselskapet, jf. § 8(1).

Forsikringsgiverne dekker uforsikret institusjon i fellesskap, jf. § 8(2). ${ }^{39}$

Oppsummering av pasientskadeansvaret

\begin{tabular}{|l|l|}
\hline Systematiseringskriterier & Beskrivelse \\
\hline Erstatningsområde & Personskade som følge av behandling i helseinstitusjon \\
\hline Ytelsespliktig & Norsk Pasientskadeerstatning eller forsikringsselskap \\
\hline Kriterier for ansvar & Lidt tap på grunn av pasientskade \\
\hline Utmåling / ytelsens karakter & Tapt inntekt, tap i fremtidig inntekt / engangsytelse \\
\hline Reduksjon/bortfall & Medvirkning jf. skl § 5-1 og lempning jf. skl § 5-2 \\
\hline Samordning & Med andre erstatnings-, trygde- og forsikringsytelser \\
\hline Sikkerhet for ytelse & Statsgarantert (NPS) eller forsikringsselskaps betalingsevne \\
\hline Skatt & Skatt på tapt inntekt, ikke skatt på tapt fremtidig inntekt \\
\hline
\end{tabular}

\section{Yrkesskadeansvaret}

Yrkesskadeansvaret som har hjemmel i lov om yrkesskadeforsikring av 16. juni 1989 nr.

65. Her pålegges arbeidsgiver å tegne yrkesskadeforsikring for sine ansatte. Dette gir arbeidstaker rett på erstatning, direkte fra arbeidsgivers forsikringsselskap, ved sykdom eller skade som vedkommende påføres i arbeidet på arbeidsstedet i arbeidstiden, jf. § 10 . Forsikringsgiverne dekker tapet i fellesskap ved manglende forsikring.

Erstatningsutmålingen er i stor grad standardisert, se §13, jf. forskrift om standardisert erstatning etter yrkesskadeforsikringsloven. ${ }^{40}$

Utover den generelle medvirkningsregelen i skadeserstatningsloven § 5-1 har yrkesskadeforsikringsloven spesielle regler i § 14. Det følger her at erstatningen kan settes ned eller falle helt bort, ikke bare dersom arbeidstaker har medvirket forsettelig til skaden, men også dersom medvirkningen har vært grovt uaktsom. ${ }^{41}$

Yrkesskadeansvaret fremstilt etter systematiseringskriteriene:

\begin{tabular}{|l|l|}
\hline Systematiseringskriterier & Beskrivelse \\
\hline Erstatningsområde & Skade eller sykdom i arbeid \\
\hline Ytelsespliktig & Arbeidsgivers forsikringsselskap, evt. forsikringsgivere i fellesskap \\
\hline Kriterier for ansvar & Yrkesskade/sykdom - i arbeidet, på arbeidsstedet, i arbeidstiden \\
\hline Utmåling / ytelsens karakter & Tapt inntekt og fremtidig tap etter standardiserte regler / engangsytelse \\
\hline Reduksjon/bortfall & Forsettelig el. grovt uaktsom medvirkning, jf. yforsl §14 og lempning jf.skl §5-2 \\
\hline Samordning & Med andre erstatnings-, trygde- og forsikringsytelser \\
\hline Sikkerhet for ytelse & Forsikringsselskaps betalingsevne \\
\hline Skatt & Skatt på tapt inntekt, ikke skatt på tapt fremtidig inntekt \\
\hline
\end{tabular}

${ }^{39}$ Peter Lødrup, Lærebok i erstatningsrett, Oslo 1999 s. 235-240.

${ }^{40}$ Peter Lødrup, Lærebok i erstatningsrett, Oslo 1999 s. 214-218.

${ }^{41}$ Lars Olav Skårberg og Marianne Reusch, Yrkesskade, Oslo 2003 s. 101-107. 


\section{Arbeidsgiveransvaret}

Arbeidsgiveransvaret er hjemlet i skadeserstatningsloven av 13. juni 1969 nr. 26 kapittel 2. Arbeidsgiver blir ansvarlig på objektivt grunnlag for skade som arbeidstaker påfører andre under utførelsen av arbeidet. Det er en forutsetning at arbeidstaker har utvist skyld, altså opptrådt forsettelig eller uaktsomt. Arbeidsgiver blir med andre ord solidarisk ansvarlig med arbeidstaker. ${ }^{42}$

Oppsummert fremstår arbeidsgiveransvaret som følger:

\begin{tabular}{|l|l|}
\hline Systematiseringskriterier & Beskrivelse \\
\hline Erstatningsområde & Skade utført av arbeidstaker \\
\hline Ytelsespliktig & Arbeidsgiver \\
\hline Kriterier for ansvar & Arbeidstaker opptrer forsettelig eller uaktsomt \\
\hline Utmåling / ytelsens karakter & Tapt inntekt, tap i fremtidig inntekt / engangsytelse \\
\hline Reduksjon/bortfall & Medvirkning jf. skl §§ 5-1 og lemping etter 2-2 (1), jf. 5-2 \\
\hline Samordning & Med andre erstatnings-, trygde- og forsikringsytelser \\
\hline Sikkerhet for ytelse & Arbeidsgivers betalingsevne, evt. ansvarsforsikring \\
\hline Skatt & Skatt på tapt inntekt, ikke skatt på tapt fremtidig inntekt \\
\hline
\end{tabular}

\section{Voldsoffererstatningen}

I tillegg finnes en rekke erstatningsordninger hvor det offentlige kan yte erstatning. Den viktigste av disse, i denne sammenheng, er voldsoffererstatningen. Denne erstatningsordningen har hjemmel i lov om erstatning fra staten for personskade voldt ved straffbar handling med m.m. av 20. april 2001 nr. 13. Søker gis rett til erstatning fra staten dersom vilkårene om personskade som følge av voldshandling er oppfylt, jf. §1. Dette erstatningsgrunnlag gir rett til erstatning av staten, uavhengig av statens skyld.

Voldsoffererstatning utmåles etter reglene i skadeserstatningsloven § 3-1 (2), med et tak på kr $1.000 .000 .^{43}$

Voldsoffererstatningen kan oppsummeres som følger:

\begin{tabular}{|l|l|}
\hline Systematiseringskriterier & Beskrivelse \\
\hline Erstatningsområde & Erstatning til voldsofre \\
\hline Ytelsespliktig & Staten \\
\hline Kriterier for ansvar & Personskade som følge av voldshandling \\
\hline Utmåling / ytelsens karakter & Tapt inntekt, tap i fremtidig inntekt, maks 1.000.000 / engangsytelse \\
\hline Reduksjon/bortfall & Medvirkning jf. skl § 5-1 og lempning jf. skl § 5-2 \\
\hline Samordning & Med andre erstatnings-, trygde- og forsikringsytelser \\
\hline Sikkerhet for ytelse & Statsgarantert \\
\hline Skatt & Skatt på tapt inntekt, ikke skatt på tapt fremtidig inntekt \\
\hline
\end{tabular}

42 Peter Lødrup, Lærebok i erstatningsrett, Oslo 1999 s. 171-194.

${ }^{43}$ Ane Sofie Tømerås, Billighetserstatning og andre offentlige erstatningsordninger, Oslo 2002 s. 28-35. 


\subsection{Trygderett og arbeidsuførhet}

\subsubsection{Generelt}

\section{Opprinnelse og utvikling}

Fra midten av 1800-tallet førte samfunnsutviklingen til at datidens ordninger om underhold ikke lenger strakk til. Industrialisering og endring av familiestruktur var de viktigste årsakene. Som følge av dette startet en prosess hvor forskjellige støtteordninger gradvis ble utviklet. Utviklingen har pågått helt frem til i dag, hvor folketrygdloven av 1997 er den viktigste formelle rettskilde. ${ }^{44}$

\section{Hovedhensyn bak trygderetten}

Trygderetten har som formål å gi økonomisk trygghet i visse situasjoner. Dette følger av folketrygdloven § 1-1. For reglene som skal behandles her er formålet - helt eller delvis - å kompensere bortfall av inntekt som følge av arbeidsuførhet. Det er altså et reparasjonsmotiv som dominerer trygderettens regler.

Måten trygdeytelser finansieres på fører til en fordeling av kostnaden på store deler av samfunnet. Folketrygden finansieres av arbeidstakere gjennom trygdeavgiften, arbeidsgivere gjennom arbeidsgiveravgiften og gjennom statstilskudd, jf. folketrygdloven kapittel 23. Trygderetten ivaretar altså også hensynet til en fordeling av tap som følge av arbeidsuførhet.

\section{Rettskildesituasjonen}

Lov- og forskriftsmengden i trygderetten er omfattende. Folketrygdloven av 28. februar 1997 nr. 19 er sentral her. Lovforarbeider samt annet bakgrunnsstoff er også rettskilder som har vekt.

Praksis fra trygdeadministrasjonen og Trygderetten har på mange områder stor rettskildemessig vekt. Ordinær rettspraksis har det vært mindre av på trygderettens område. Dette skyldes i stor grad Trygderettens noe spesielle domstolsfunksjon på rettsområdet.

${ }^{44}$ Asbjørn Kjønstad, Innføring i trygderett, 3. utg, Oslo 1998 s. 17-19. 
Men i de senere år har likevel en rekke saker blitt brakt inn for lagmannsretten. Det har også blitt avsagt enkelte viktige dommer fra høyesterett.

Reelle hensyn kan i enkelte tilfeller ha stor vekt. F.eks kan samfunnsøkonomiske konsekvenser ved utvidende tolkninger av trygderettigheter få betydning. ${ }^{45}$

\section{Samordning}

På trygdrettens område er det mindre muligheter for samordning. Folketrygdens ytelser kan ikke nedsettes eller bortfalle på grunn av ytelser fra skadeserstatning eller forsikring. ${ }^{46}$ Uførepensjonen kan imidlertid reduseres med pensjonslignende ytelser fra arbeidsgiver. Dette følger av folketrygdloven § 12-17. Utover dette reduseres ikke ytelsene.

\section{Trygd og skatt}

Folketrygdens uførepensjon og yrkesskadetrygd skal, ifølge skatteloven av 26. mars 1999 nr. 14 § 5-1 første ledd, betraktes som skattepliktig inntekt. Det benyttes lav sats for folketrygdavgift, som pt. er 3.0 prosent. ${ }^{47}$ Det gis særfradrag i alminnelig inntekt for mottakere av uførepensjon når inntektsevnen er nedsatt med minst 2/3. Dette følger av skatteloven § 6-81 (2). Særfradraget utgjør kr 1.530 pr. måned. ${ }^{48}$

\section{Sikkerhet for ytelser}

Når et krav har sitt grunnlag i folketrygdloven eller denne lovs forskrifter, er det folketrygden som skal yte. Etter bestemmelsene i folketrygdloven kapittel 23, er det staten som er ansvarlig for å finansiere den del av folketrygdens ytelser som ikke dekkes gjennom avgifter. Et krav mot folketrygden må derfor kunne betraktes som sikkert. Lovgiver har imidlertid anledning til å endre trygdereglene med den følge at ytelser reduseres eller faller bort. ${ }^{49}$ Men denne adgangen er begrenset gjennom Grunnlovens § 97, som pålegger lovgiver å respektere tidligere stiftede rettigheter. Rekkevidden av dette vern ble behandlet i bl.a Borthendommen, Rt 1996, s. 1415. Høyesteretts praksis har vært at

\footnotetext{
${ }^{45}$ Gudrun Holgersen og Nils Nygaard, Trygdrettslige emner, Bergen 1998 s. 29-42.

${ }^{46}$ Asbjørn Kjønstad, Erstatningsretten i utvikling, Oslo 2003 s. 92.

${ }^{47}$ Finansdepartementet, Skattesatser og beløpsgrenser mv. for 2003 og 2004, www.odin.no/fin

${ }^{48}$ Finansdepartementet, Skattesatser og beløpsgrenser mv. for 2003 og 2004, www.odin.no/fin

${ }^{49}$ Se nærmere Johs. Andenæs, Statsforfatningen i Norge, 8. utg, Oslo 1998 s. 418-424.
} 
pensjonsrettigheter har et visst vern etter § 97 mot fremtidig lovgivning. Det avgjørende vil være om domstolene finner den nye lovgivningen å være klart urimelig eller urettferdig. ${ }^{50}$

\section{Grunnlag for trygdeytelser}

Ytelser fra folketrygden har sitt grunnlag i lov om folketrygd av 28. februar 1997 nr. 19. Loven er et omfattende regelverk som regulerer ytelser på en rekke områder. Ytelsene fra folketrygden kan deles inn i tre hovedkategorier: korttidsytelser, ytelser i omstillingsperioder og langtidsytelser. ${ }^{51}$ Siden det i denne sammenheng er avgrenset mot korttidsytelser, er det langtidsytelsene som er av størst interesse. Enkelte overgangsytelser kan imidlertid også være aktuelle siden det kan gå flere år fra uførhet inntreffer til uførepensjon blir innvilget. Dette gjeldet ytelser til rehabilitering og attføring, som har store likhetstrekk med langtidsytelsene. Overgangsytelsene blir ikke ytterligere omtalt.

På trygderettens område vil den uføre ha rett til ytelser uavhengig av hvor ansvaret for hendelsen som har medført uførhet, kan plasseres. I figur 3 er dette illustrert for folketrygdens uførepensjon. Med andre ord gis ytelsene på grunnlag av følgen, altså arbeidsuførhet, uavhengig av hva som er årsaken.

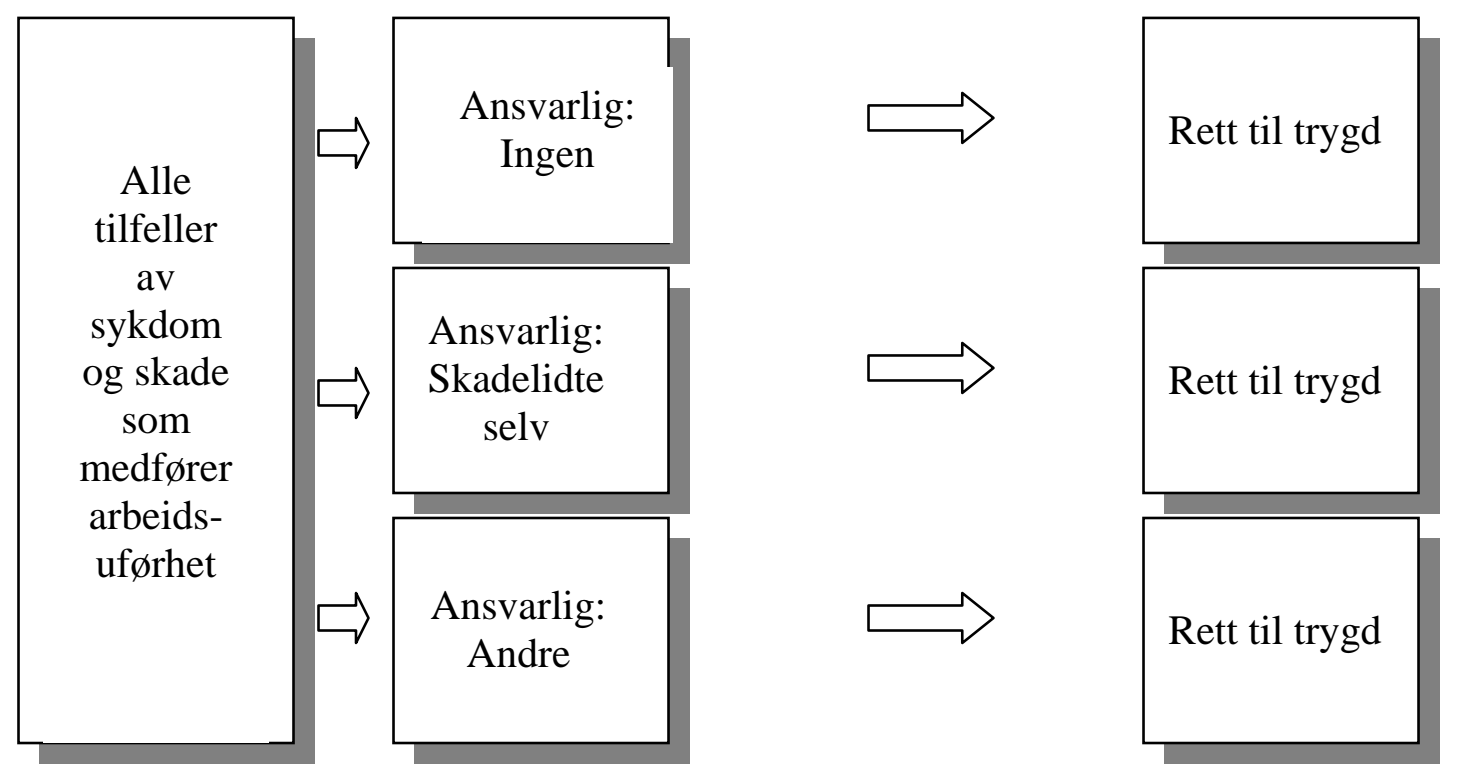

Figur 3: Sammenhengen mellom skade- og sykdomstilfeller og grunnlag for trygdeytelser

${ }^{51}$ Asbjørn Kjønstad, Innføring i trygderett, 3. utg, Oslo 1998 s. 25-26. 
Aktuelle ytelser fra folketrygden ved varig arbeidsuførhet er uførepensjon som er hjemlet i folketrygdloven kapittel 12. Dertil kan gis særskilte yrkesskadeytelser for sykdommer og skader som følger av kapittel 13. I det følgende kommer jeg til å behandle den ordinære uførepensjonen etter kapittel 12 og uførepensjon ved arbeidsuførhet etter kapittel 13 som to atskilte grunnlag for trygdeytelser. Dette gjøres for å få frem de to variantenes særegenheter.

\subsubsection{Ordinær uførepensjon}

Uførepensjonens formål er, som det fremgår av § 12-1, å sikre inntekt for personer som har fått sin inntektsevne eller arbeidsevne nedsatt. Det stilles flere vilkår for at uførepensjon skal kunne innvilges. Disse følger av §§ 12-2 til 12-7. For det første må vedkommende, med visse unntak, ha vært medlem i folketrygden en forutgående periode og fremdeles være det. For det andre må vedkommende være mellom 18 og 67 år. For det tredje skal behandling være forsøkt. For det fjerde må uførheten skyldes sykdom, skade eller lyte. Den må altså ha en medisinsk årsak. For det femte må ervervsevnen være varig nedsatt med minst 50 prosent. $^{52}$

Folketrygdloven inneholder detaljerte regler om hvordan de forskjellige trygdeytelser skal utmåles. Reglene om utmåling av uførepensjon står i folketrygdloven kapittel 3, jf. § 1213.

Ytelser ved uførepensjon består av grunnpensjon, tilleggspensjon og/eller særtillegg. Grunnpensjonen er i utgangspunktet 1G, men for pensjonist som bor sammen med ektefelle, registrert partner og samboer er den 82,5 prosent ${ }^{53}$ av G. Tilleggspensjon beregnes med utgangspunkt i tidligere opptjente pensjonspoeng og antall poengår. Særtillegget utgjør en prosentandel av G og ytes til personer som ikke har rett til eller bare har rett til lav tilleggspensjon.

\footnotetext{
${ }^{52}$ Asbjørn Kjønstad, Innføring i trygderett, 3. utg, Oslo 1998 s. 125-133.

53 Trygdeetaten.no, Satser, http://www.trygdeetaten.no (23.10.04)
} 
Uførepensjonen kan oppsummeres slik:

\begin{tabular}{|l|l|}
\hline Systematiseringskriterier & Beskrivelse \\
\hline Erstatningsområde & Bortfall av arbeidsevne \\
\hline Ytelsespliktig & Folketrygden \\
\hline Kriterier for ansvar & Minst 50\% varig arbeidsufør, forsøkt behandling og attføring \\
\hline Utmåling / ytelsens karakter & Lovbestemt utregning / månedlig \\
\hline Reduksjon/bortfall & Ved 67 år og endring i helsetilstand, ikke ved medvirkning \\
\hline Samordning & Med pensjonslignende ytelser fra arbeidsgiver \\
\hline Sikkerhet for ytelse & Statsgarantert, men mulighet for regelendring \\
\hline Skatt & Som pensjonsinntekt, med mulig særfradrag \\
\hline
\end{tabular}

\subsubsection{Uførepensjon ved yrkesskade}

Reglene om folketrygdens yrkesskadedekning er å finne i folketrygdloven kapittel 13.

Uførepensjon ved yrkesskader bygger på samme prinsipper som ordinær uførepensjon etter folketrygdloven kapittel 12, men har enkelte avvik til fordel for den uføre.

Loven gir detaljerte bestemmelser om i hvilke sammenhenger en person skal anses for å være dekket av uførepensjon ved yrkesskade. Det er sykdom eller skade som følge av arbeidsulykke som er dekket. Dette innebærer at hendelsen må være plutselig, uforutsett og stå i sammenheng med arbeidet. Skade som inntrer litt etter hvert er ikke yrkesskade. Som det følger av § 13-1 er formålet med denne dekningen å gi særfordeler utover trygdens ordinære stønadssystem. Det er altså meningen å gi bedre dekning ved uførhet påført i yrke enn utenfor. ${ }^{54}$

Uførepensjon ved yrkesskade gir pensjon med utgangspunkt i samme regler som for ordinær uførepensjon. Det finnes imidlertid en del særlige bestemmelser for disse tilfellene. Der det utenfor yrkesskade kreves minst 50\% uføregrad for å få rett på pensjon, kreves det ved yrkesskade kun 30\%. Videre gjelder ikke de ordinære reglene om medlemstid og fortsatt medlemskap. ${ }^{55}$

Utmålingen av uførepensjon ved yrkesskade foretas etter reglene i folketrygdloven § 3-30. Den viktigste forskjellen, i forhold til ordinær uførepensjon, er at pensjonsytelsene ikke reduseres dersom den uføre har opptjent mindre enn 40 års trygdetid og poengår.

\footnotetext{
${ }^{54}$ Asbjørn Kjønstad, Yrkesskadetrygden, Oslo 1979 s. 51-54.

${ }^{55}$ Se folketrygdloven $§ 12-18$.
} 
Yrkesskadetrygden fremstilt etter systematiseringsvariablene:

\begin{tabular}{|l|l|}
\hline Systematiseringskriterier & Beskrivelse \\
\hline Erstatningsområde & Bortfall av arbeidsevne som følge av yrkesskade \\
\hline Ytelsespliktig & Folketrygden \\
\hline Kriterier for ansvar & Minst 30\% varig arbeidsufør, forsøkt behandling og attføring \\
\hline Utmåling / ytelsens karakter & Lovbestemt utregning / månedlig \\
\hline Reduksjon/bortfall & Ved 67 år og endring i helsetilstand, ikke ved medvirkning \\
\hline Samordning & Med pensjonslignende ytelser fra arbeidsgiver \\
\hline Sikkerhet for ytelse & Statsgarantert, men mulighet for regelendringer \\
\hline Skatt & Som pensjonsinntekt, med mulig særfradrag \\
\hline
\end{tabular}




\subsection{Forsikringsrett og arbeidsuførhet}

\subsubsection{Generelt}

\section{Opprinnelse og utvikling}

Forsikringsvirksomheten har utviklet seg til å bli meget omfattende. I dag finnes et utall av forsikringsprodukter som er tilpasset ulike formål. Forsikringsvirksomhet hadde sin spede begynnelse allerede i det 5 . århundre f.Kr. Utviklingen av moderne forsikringsvirksomhet skjedde imidlertid ikke før på 1500-tallet. ${ }^{56}$ Hovedårsaken til utviklingen har vært endrede behov som følge av samfunnsutviklingen.

Ifølge Statistisk Sentralbyrå betalte norske forsikringstakere ca 90 milliarder kroner i forsikringspremier i 2003. Av disse gikk bortimot 60 milliarder til personforsikring. ${ }^{57}$ Til sammenligning utgjorde medlemsavgiften i folketrygden ca 60 milliarder og arbeidsgiveravgiften ca 82 milliarder. $^{58}$

\section{Hovedhensynene bak forsikringsretten}

Forsikring går i korte trekk ut på risikooverføring mot vederlag. ${ }^{59}$ Muligheten for å overføre risiko til et forsikringsselskap og på denne måte skape økonomisk trygghet, er en viktig samfunnsfunksjon og en forutsetning for at samfunnet skal kunne fungere effektivt. ${ }^{60}$ Dette er egentlig en virkning av at eventuelle fremtidig tap pulveriseres og fordeles på store deler av samfunnet. Ved å fordele de totale kostnadene ved forsikringsvirksomheten på forsikringstakerne, elimineres risikoen for den enkelte. I noen tilfeller anses dette prinsippet som så viktig at det er innført forsikringsplikt.

Hensynet til god fordeling står altså sterkt innen forsikringsretten. For den enkelte forsikringstaker er nok likevel reparasjonshensynet det viktigste. I mange tilfeller vil en forsikringsdekning gi kompensasjon hvor det ellers ikke ville være grunnlag for ytelse.

\footnotetext{
${ }^{56}$ Norges Forsikringsforbund, Håndbok i forsikring, s. 10-11.

${ }^{57}$ Statistisk Sentralbyrå, Livs- og skadeforsikringsselskaper 2004, www.ssb.no

${ }^{58}$ Trygdeetaten, Trygdeetatens årbok 2003, www.trygdeetaten.no

${ }^{59}$ Knut S. Selmer, Forsikringsrett, Oslo 1982 s. 1.

${ }^{60}$ Norges Forsikringsforbund, Håndbok i forsikring, s.12-13.
} 


\section{Rettskildesituasjonen}

Rettigheter og plikter i forsikringssammenheng oppstår vanligvis som følge av avtale mellom forsikringstaker og forsikringsselskap. Dette kan for det første være avtaler som gir forsikringstaker selv rett til ytelser i visse sammenhenger. For det andre kan det være avtaler som tar sikte på å dekke tredjemanns tap. ${ }^{61}$

Mange forsikringsavtaler inngås individuelt. Avtalene bygger likevel i stor utstrekning på standardvilkår. Det samme gjelder for kollektive forsikringsavtaler. Praksis har følgelig betydning som rettskilde.

Også på dette rettsområdet er lov en viktig rettskilde. Det finnes en rekke lover og forskrifter som regulerer forsikringsavtaler og forsikringsvirksomhet. Den viktigste er lov om forsikringsavtaler av 16. juni 1989 nr. 69. Dette er regler som i stor grad tar sikte på å unngå urimelige utslag for forsikringstaker. ${ }^{62}$

Enkelte hendelser kan være dekket av forsikring selv om avtale ikke foreligger. Et eksempel på dette er skade som ukjent eller uforsikret motorvogn gjør. Her er skadelidte dekket av trafikkforsikringsselskapene i fellesskap, jf. bilansvarsloven $§ 10$.

\section{Samordning}

Forsikringsytelser ytes i utgangspunktet uavhengig av andre ytelser. Det eksisterer ikke noe "berikelsesforbud" i norsk forsikringsrett. ${ }^{63}$ Det er opp til avtalepartene i et forsikringsforhold å bestemme omfanget av den enkelte forsikringsdekning, og dermed også hvilken økonomisk gevinst som kan oppnås. Av denne grunn er det, i enkelte sammenhenger, tatt inn bestemmelser i forsikringsavtale og -vilkår som begrenser ytelsen. Dette gjelder ved terminvise uføreytelser. Det er her vanlig å begrense ytelsene til, sammen med øvrige ytelser, å ikke overstige en viss andel av tidligere lønnsinntekt. Dette fremgår av det enkelte forsikringsselskaps forsikringsvilkår. F.eks begrenser forsikringsselskapet Storebrand sin ytelse, sammen med alle andre ytelser, til å ikke overstige 80\% av gjennomsnittlig arbeidsinntekt siste 2 år. $^{64}$

\footnotetext{
${ }^{61}$ Knut S. Selmer, Forsikringsrett, Oslo 1982 s. 52-52.

62 Norges Forsikringsforbund, Håndbok i forsikring, Oslo 1995 s. 25-28.

${ }^{63}$ Hans Jacob Bull, Innføring i forsikringsrett, Oslo 2000 s. 456.
} 


\section{Forsikring og skatt}

Forsikringsytelser er i varierende grad underlagt beskatning. Uførerenter blir beskattet forskjellig på bakgrunn av sammenhengen den er etablert i. Er disse individuelt etablert, vil normalt 20 prosent av ytelsen være skattepliktig som alminnelig inntekt. ${ }^{65}$ Unntaket er hvis den er etablert innenfor en IPA-ordningen. Her vil hele ytelsen være skattepliktig, jf. skatteloven § 12-2 d, mens innbetalt premie vil være fradragsberettiget, jf. skatteloven § 6-47 c. Dersom uførerenten er etablert kollektivt i arbeidsforhold, vil ytelsen alltid betraktes som skattepliktig personinntekt, jf. skatteloven § 12-2 b. Dersom den ansatte har bidratt med tilskudd, er dette fradragsberettiget ifølge skatteloven § 6-47 a, b og d. Det er her en betingelse at ordningen er etablert innenfor spesielle rammer, f.eks lov om foretakspensjon av 24. mars $2000 \mathrm{nr} .16$.

Engangsutbetalinger fra kapitalforsikringer er ikke skattepliktige, jf. skatteloven § 5-21 (2). Hvis ordningen er etablert i arbeidsforhold, vil den premien som betales, bli å betrakte som et skattepliktig tillegg til lønn, ${ }^{66}$ jf. skatteloven § 5-10 a.

Ytelser fra ansvarsforsikringer trer i stedet for skadevolders ytelse og er følgelig skattepliktige på samme måte som skadeserstatning. ${ }^{67}$ Jeg viser derfor til fremstillingen i kapittel 2.2.1.

\section{Sikkerhet for ytelser}

En ytelse som har sitt grunnlag i en forsikringsavtale, dekkes av forsikringsselskapets midler. Regler om hvordan et forsikringsselskap skal organiseres finnes i lov om forsikringsvirksomhet av 10. juni 1988 nr. 39. Forsikringsbransjen er underlagt regler som bl.a. regulerer hvor stor risiko selskapet kan eksponere seg for i forhold til dets økonomiske bæreevne. ${ }^{68}$

De fleste forsikringsselskaper benytter seg av reassuranse. ${ }^{69}$ Dette går i korte trekk ut på at det enkelte selskap overfører risiko til andre forsikringsselskaper mot en del av premien. På denne måten kan det enkelte selskap tilpasse risikoen til den økonomiske bæreevne, og

\footnotetext{
${ }^{64}$ Storebrand, Forsikringsvilkår for livkonto, september 2003 s. 12.

${ }^{65}$ Følger av forskrift etter skatteloven § 5-41(1).

${ }^{66}$ Norges Forsikringsforbund, Håndbok i forsikring, Oslo 1995 s. 140.

${ }^{67}$ Knut S. Selmer, Forsikringsrett, Oslo 1982 s. 130-131.

${ }^{68}$ Norges Forsikringsforbund, Håndbok i forsikring, Oslo 1995 s. 25.
} 
store uventede utbetalinger kan skyves over på forsikringsbransjen i fellesskap. Resultatet blir at forsikringsselskapets soliditet opprettholdes.

Man kan derfor anse det som sikkert at et forsikringsselskap vil kunne oppfylle sine forpliktelser. Dette selv om det eksisterer en teoretisk risiko for at mange store og samtidige skader vil kunne overstige forsikringsselskapenes betalingsevne.

\section{Grunnlag for forsikringsytelser}

Jeg skal i dette avsnitt gi en oversikt over hvilke hovedtyper av forsikringsytelser som kan være relevante ved arbeidsuførhet. I forhold til konsekvensene som følger av bortfalt arbeidsevne, er det tre grupper av forsikringer som er av interesse. For det første har vi forsikringsformen personforsikring med forskjellige undergrupper. For det andre har vi ansvarsforsikring, som er en undergruppe av skadeforsikring. For det tredje finnes en gruppe forsikringer som går under betegnelsen "no-fault”-forsikringer. Den sistnevnte etableres av den potensielle skadevolder til fordel for den skadelidte og kommer i en mellomstilling mellom person og ansvarsforsikring.

Figur 4 viser, med utgangspunkt i alle tilfeller av sykdom og skade som medfører arbeidsuførhet, hvilke situasjonstyper som gir grunnlag for forsikringsytelser. En del av hendelsene som ingen er ansvarlige for, og en del av hendelsene som skadelidte selv er ansvarlig for, dekkes av personforsikring. Videre dekkes en del av hendelsene som andre er ansvarlige for av personforsikring og/ eller ansvarsforsikring.

Det vil altså kunne være grunnlag for forsikringsytelser uavhengig av hvem som er ansvarlig for skaden.

Men en rekke hendelser vil være unntatt dekning. I de tilfellene hvor ingen er ansvarlige for uførheten, vil en rekke situasjoner være unntatt ved forsikringsavtale- og vilkår.

I de tilfeller hvor den uføre selv har skapt situasjonen som har medført uførheten, vil ytelser kunne avskjæres helt eller delvis dersom vedkommende har opptrådt uaktsomt eller med forsett. Dette gjelder også hvis begrensninger er avtalt.

${ }^{69}$ Norges Forsikringsforbund, Håndbok i forsikring, Oslo 1995 s. 143-146. 


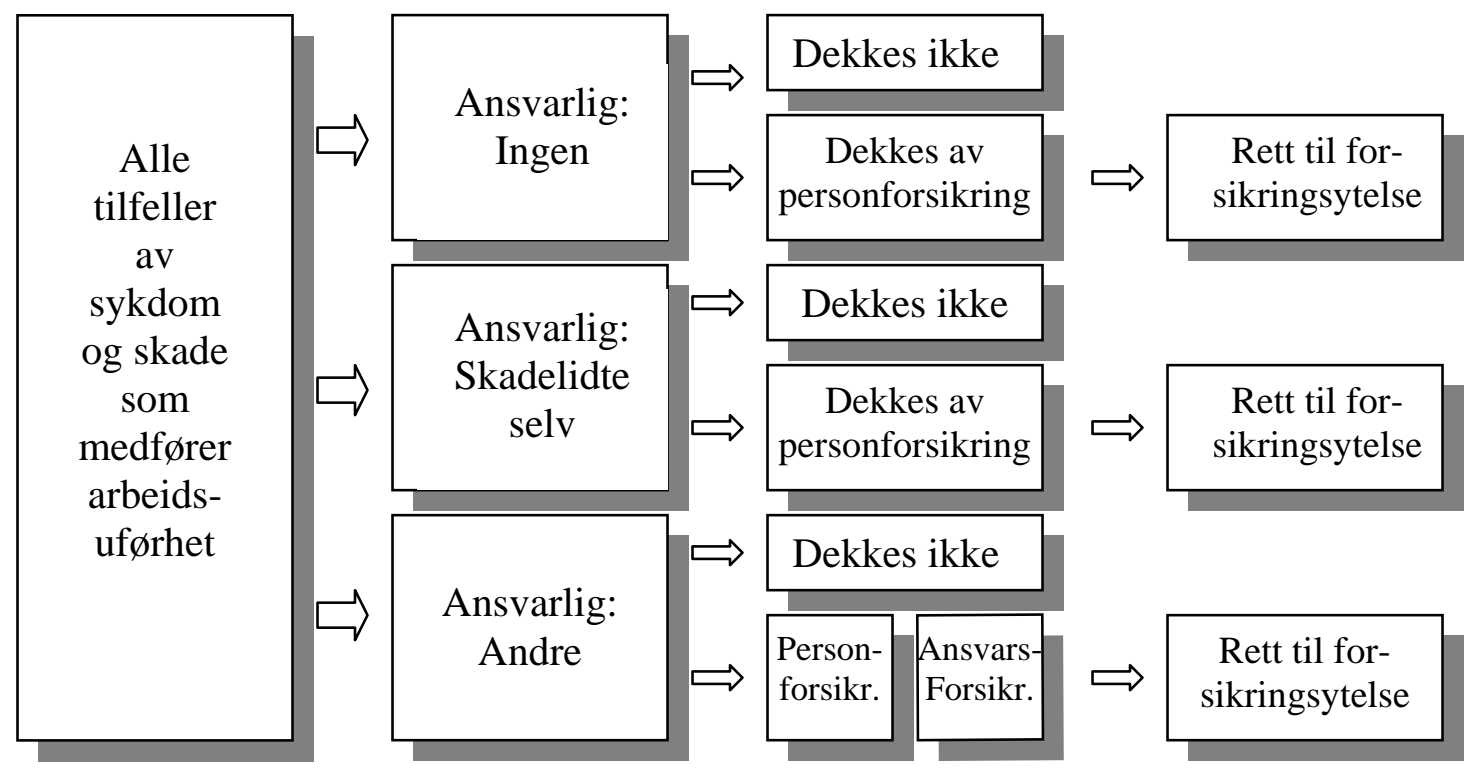

Figur 4: Sammenhengen mellom skade- og sykdomstilfeller og grunnlag for forsikringsytelser

I den grad andre er ansvarlige, kan erstatning falle bort som følge av at den uføre har medvirket eller det kan være avtalt begrensninger i dekningsomfanget. Dette gjelder både i forhold til personforsikring og ansvarsforsikring.

\subsubsection{Personforsikring}

Personforsikring dreier seg om ytelser ved følgende hendelser: uførhet, død og oppnådd alder. Under hver av disse hovedgruppene finnes det et stort antall forskjellige forsikringsprodukter som kan gi grunnlag for ytelser ved arbeidsuførhet. Videre kan de forskjellige ytelser være periodiske eller engangs. Ofte er de forskjellige ytelsene sammensatt for å dekke et individuelt behov. ${ }^{70}$

Personforsikringer etableres i utgangspunktet av den enkelte med tanke på å redusere tap som følge av hendelser som griper økonomisk inn i tilværelsen. Dekningene kan imidlertid også etableres av andre, for eksempel arbeidsgiver til fordel for ansatte. ${ }^{71}$ Slike dekninger kan være en del de ansattes rettigheter som er knyttet arbeidsavtalen, og beregnes etter andre tariffer enn individuelle dekninger.

${ }^{70}$ Knut S. Selmer, Forsikringsrett, Oslo 1982 s. 136. 
Ytelser fra personforsikringsdekninger utmåles etter en bestemt forsikringssum, som er avtalt på forhånd. Normalt graderes forsikringsytelsen i forhold til omfanget av uførheten.

Forsikringsytelsen kan imidlertid settes ned eller falle helt bort dersom forsikrede har fremkalt forsikringstilfellet forsettelig eller uaktsomt eller har forsømt sin opplysningsplikt, jf. forsikringsavtaleloven $\S \S 13-2,13-8$ og 13-9.

I det følgende ser jeg nærmere på undergrupper av personforsikringsytelser som kan være av interesse ved arbeidsuførhet.

\section{Uførekapital}

Uførekapital er en forsikringsdekning som utbetales som et engangsbeløp ved uførhet. Uførebegrepet i denne sammenheng relateres til ervervsevnen. Det er uten betydning om det er sykdom eller ulykke som har forårsaket uførheten. Normalt stilles det krav om at uførheten må overstige et visst minimum, samtidig som den må kunne betegnes å være varig. $^{72}$

Uførekapitaldekningen kan oppsummeres slik:

\begin{tabular}{|l|l|}
\hline Systematiseringskriterier & Beskrivelse \\
\hline Erstatningsområde & Avtalt ytelse ved varig arbeidsuførhet \\
\hline Ytelsespliktig & Forsikringsselskap \\
\hline Kriterier for ansvar & Minst 50\% varig arbeidsufør \\
\hline Utmåling / ytelsens karakter & Etter avtalt forsikringssum / engangsytelse \\
\hline Reduksjon/bortfall & Fremkallelse jf. fal §§13-8 og 13-9, forsømt informasjonsplikt §13-2 \\
\hline Samordning & Nei \\
\hline Sikkerhet for ytelse & Forsikringsselskapets betalingsdyktighet \\
\hline Skatt & Nei \\
\hline
\end{tabular}

\section{Uførerente}

Uførerente er en forsikringsdekning som innebærer en løpende ytelse, normalt månedlig, i en bestemt periode. De forskjellige parametere fastsettes i forsikringsavtalen. For at denne ytelsen skal være berettiget, kreves at arbeidsevnen er nedsatt til et visst minimumsnivå og har en varighet utover et visst antall måneder. ${ }^{73}$

\footnotetext{
${ }^{71}$ Knut S. Selmer, Forsikringsrett, Oslo 1982 s. 49-50.

${ }^{72}$ Norges Forsikringsforbund, Håndbok i forsikring, Oslo 1995 s. 128.

${ }^{73}$ Norges Forsikringsforbund, Håndbok i forsikring, Oslo 1995 s. 130.
} 
Uførerente kan sammenfattes tabellarisk etter systematiseringskriteriene som følger:

\begin{tabular}{|l|l|}
\hline Systematiseringskriterier & Beskrivelse \\
\hline Erstatningsområde & Avtalt ytelse ved varig arbeidsuførhet \\
\hline Ytelsespliktig & Forsikringsselskap \\
\hline Kriterier for ansvar & Minst 25\% arbeidsufør (ikke varig) \\
\hline Utmåling / ytelsens karakter & Etter avtalt forsikringssum / månedlig ytelse \\
\hline Reduksjon/bortfall & $\begin{array}{l}\text { Ved nådd alder, endring i helsetilstand, fremkallelse jf. fal §§ 13-8, 13-9 } \\
\text { og forsømt informasjonsplikt jf. §13-2 }\end{array}$ \\
\hline Samordning & Med andre ytelser ut over et visst nivå \\
\hline Sikkerhet for ytelse & Forsikringsselskapets betalingsdyktighet \\
\hline Skatt & Som alminnelig inntekt (med 20\%), eller som pensjonsinntekt \\
\hline
\end{tabular}

\section{Ulykkesforsikring - uførhet}

Denne forsikringsdekningen baseres på en medisinsk, ikke ervervsmessig uførevurdering. ${ }^{74}$

Medisinsk uførhet fastsettes i forhold til omfanget av skade uavhengig av om arbeidsevnen er påvirket, og faller derfor utenfor grensene for denne fremstillingen. Grunnen til at jeg likevel omtaler ulykkesforsikring, er at den i stor grad benyttes for å dekke tap som følge av arbeidsuførhet. ${ }^{75}$ Dette til tross for at den har begrenset nedslagsfelt.

En ulykkesforsikring vil bare være aktuell ved ulykkesskade. ${ }^{76}$ Sykdomstilfeller og skade som har sin opprinnelse på annen måte enn fra ulykke, er ikke dekket. Siden andelen av totale uføretilfeller som stammer fra ulykker er liten, ${ }^{77}$ er dette en ytelse som har begrenset funksjon som risikoavlaster. Årsak til at denne forsikringstypen likevel blir valgt for å dekke økonomisk tap ved arbeidsuførhet, kan være lav pris og mangel på forståelse av dekningsomfang.

Dekningen kan oppsummeres slik:

\begin{tabular}{|l|l|}
\hline Systematiseringskriterier & Beskrivelse \\
\hline Erstatningsområde & Avtalt ytelse ved medisinsk uførhet \\
\hline Ytelsespliktig & Forsikringsselskap \\
\hline Kriterier for ansvar & Fysisk eller psykisk funksjonsnedsettelse som følge av ulykke \\
\hline Utmåling / ytelsens karakter & Etter avtalt forsikringssum / engangsytelse \\
\hline Reduksjon/bortfall & Fremkallelse jf. fal §§13-8 og 13-9, forsømt informasjonsplikt jf.§13-2 \\
\hline Samordning & Nei \\
\hline Sikkerhet for ytelse & Forsikringsselskapets betalingsdyktighet \\
\hline Skatt & Nei \\
\hline
\end{tabular}

\footnotetext{
${ }^{74}$ Norges Forsikringsforbund, Håndbok i forsikring, Oslo 1995 s. 122.

${ }^{75}$ Forsikringsakademiet, Ulykkesforsikring, Oslo 1999, s. 12

${ }^{76}$ Forsikringsakademiet, Ulykkesforsikring, Oslo 1999, s. 96-100.
} 


\subsubsection{Ansvarsforsikring}

Også den som er potensiell skadevolder kan redusere sin risiko. Gjennom en ansvarsforsikring kan man dekkes mot et eventuelt erstatningsansvar som pådras etter erstatningsretten. Ansvaret det er aktuelt å dekke i denne sammenheng, er i utgangspunktet, det samme som ved skadeserstatningstilfeller, jf. punkt 2.2.1. Men det finnes viktige unntak. For det første dekker ikke ansvarsforsikringer skadevolders forsettelige handlinger. Videre er forsikringsselskapets ansvar begrenset av forsikringsavtalen, hvor det kan være inntatt reservasjoner. Ansvarsforsikringer finnes i stort omfang og er normalt inkludert i hjem/villa forsikringer og i bedriftsforsikringer. ${ }^{78}$

Ytelser fra ansvarsforsikringer baseres i utgangspunktet på erstatningsrettens utmålingsregler, jf. punkt 2.2.1. Men siden ytelsene baseres på forsikringsavtalen, vil erstatningen også avhenge av eventuelle begrensninger der. Også ytelser fra ansvarsforsikringen kan reduseres eller falle bort dersom den skadelidte har medvirket til skaden. Dette følger allerede av utmålingsreglene i erstatningsretten. Videre vil erstatning falle bort dersom sikrede, altså skadevolder, har fremkalt forsikringstilfellet forsettelig, jf. forsikringsavtaleloven $\S 4-9$.

Ansvarsforsikringen kan oppsummeres slik:

\begin{tabular}{|l|l|}
\hline Systematiseringskriterier & Beskrivelse \\
\hline Erstatningsområde & Alle \\
\hline Ytelsespliktig & Forsikringsselskap \\
\hline Kriterier for ansvar & Pådratt erstatningsansvar med enkelte unntak \\
\hline Utmåling / ytelsens karakter & Tapt inntekt, tap i fremtidig inntekt, inntil maksimumsbeløp / engangsytelse \\
\hline Reduksjon/bortfall & Medvirkning jf. skl §5-1, lempning jf. skl§5-2 og skadevolders forsett jf. fal §4-9 \\
\hline Samordning & Med andre erstatnings-, trygde- og forsikringsytelser \\
\hline Sikkerhet for ytelse & Forsikringsselskapets betalingsevne \\
\hline Skatt & Skatt på tapt inntekt, ikke skatt på tapt fremtidig inntekt \\
\hline
\end{tabular}

\footnotetext{
77 Trygdeetaten, Trygdeetatens årbok 2003, www.trygdeetaten.no (31.09.04)

${ }^{78}$ Norges Forsikringsforbund, Håndbok i forsikring, Oslo 1995 s. 63-67.
} 


\subsection{4 "No-fault"-forsikringer}

"No-fault"-forsikringene innebærer en forsikringsordning hvor skadelidtes krav mot forsikringsselskapet er uavhengig av skadevolderens personlige ansvar. Denne forsikringstypen kommer i en mellomstilling mellom personforsikring og ansvarsforsikring.

Fra forsikringstakerens synsvinkel har den samme effekt som den tradisjonelle ansvarsforsikringen bortsett fra at den i tillegg dekker hendelser som etter erstatningsretten ikke er erstatningspliktige.

Fra skadelidtes synsvinkel har forsikringen, med hensyn til skadevoldende handlinger fra forsikringstakers side, samme funksjon som en personforsikring. Ordningene er normalt etablert som et tilbud for aktører som er pålagt forsikringsplikt og er ofte kombinert med ordninger som sikrer ytelser dersom forsikringsplikten ikke er oppfylt. ${ }^{79}$

De vanligste "no-fault"-grunnlagene som gir skadelidte rett til erstatning fra forsikringsselskapene, uavhengig av skadevolders skyld, er bilansvaret, legemiddelansvaret, pasientskadeansvaret og yrkesskadeansvaret. Slike ordninger har spesielle samfunnsmessige funksjoner og er normalt regulert av egne lovbestemmelser.

De fire nevnte ansvarsgrunnlagene er de samme som flertallet av de lovfestede objektive erstatningsgrunnlagene som ble presentert i punkt 2.2.4. Sammenhengen er at lovene, i disse tilfellene, knesetter både ansvar på objektivt grunnlag og forsikringsplikt, hvor forsikringen skal dekke det objektive ansvaret. Det blir derfor to sider av samme sak, om man betrakter disse grunnlagene fra en forsikringsvinkel eller fra en skadeserstatningsvinkel.

Når det gjelder utmåling av erstatning etter "no-fault”-forsikringer, fastsettes disse etter erstatningsrettslige prinsipper, jf. punkt 2.2.1. ${ }^{80}$ Også her kan erstatningen settes ned eller

\footnotetext{
${ }^{79}$ Peter Lødrup, Lærebok i erstatningsrett, Oslo 1999 s. 68-69.

${ }^{80}$ Se f.eks produktansvarsloven $\S 2-5$
} 
falle bort dersom skadelidte har medvirket til skaden. Erstatningsutmålingen vil imidlertid ikke påvirkes av skadevolders eventuelle klanderverdige opptreden.

For oversiktens skyld gjentas oppsummeringen av de fire lovfestede objektive erstatningsgrunnlag som er dekket av lovbestemt "no-fault"-forsikring. Denne gang med forsikringsbetegnelser.

Trafikkforsikring

\begin{tabular}{|l|l|}
\hline Systematiseringskriterier & Beskrivelse \\
\hline Erstatningsområde & Skade som motorvogn gjør \\
\hline Ytelsespliktig & Motorvognens trafikkforsikringsselskap, evt. forsikringsselskap i felleskap \\
\hline Kriterier for ansvar & Skade forårsaket av motorvognen \\
\hline Utmåling / ytelsens karakter & Tapt inntekt, tap i fremtidig inntekt / engangsytelse \\
\hline Reduksjon/bortfall & Medvirkning, unntatt ved ”lite til last”, jf. bal § 7 og lempning jf. skl § 5-2 \\
\hline Samordning & Med andre erstatnings-, trygde- og forsikringsytelser \\
\hline Sikkerhet for ytelse & Trafikkforsikringsselskaps betalingsevne \\
\hline Skatt & Skatt på tapt inntekt, ikke skatt på tapt fremtidig inntekt \\
\hline
\end{tabular}

\section{Yrkesskadeforsikring}

\begin{tabular}{|l|l|}
\hline Systematiseringskriterier & Beskrivelse \\
\hline Erstatningsområde & Skade eller sykdom i arbeid \\
\hline Ytelsespliktig & Arbeidsgivers forsikringsselskap, evt. forsikringsgivere i fellesskap \\
\hline Kriterier for ansvar & Yrkesskade/sykdom - i arbeidet, på arbeidsstedet, i arbeidstiden \\
\hline Utmåling / ytelsens karakter & Tapt inntekt og fremtidig tap etter standardiserte regler / engangsytelse \\
\hline Reduksjon/bortfall & Forsettelig el. grovt uaktsom medvirkning, jf. yforsl §14 og lempning jf. skl §5-2 \\
\hline Samordning & Med andre erstatnings-, trygde- og forsikringsytelser \\
\hline Sikkerhet for ytelse & Forsikringsselskaps betalingsevne \\
\hline Skatt & Skatt på tapt inntekt, ikke skatt på tapt fremtidig inntekt \\
\hline
\end{tabular}

Legemiddelforsikringen

\begin{tabular}{|l|l|}
\hline Systematiseringskriterier & Beskrivelse \\
\hline Erstatningsområde & Følge av et legemiddels skadevoldende egenskaper \\
\hline Ytelsespliktig & Legemiddelforsikringen \\
\hline Kriterier for ansvar & Skade voldt av legemiddel \\
\hline Utmåling / ytelsens karakter & Tapt inntekt, tap i fremtidig inntekt / engangsytelse \\
\hline Reduksjon/bortfall & Medvirkning jf. skl § 5-1 og lempning jf. skl § 5-2 \\
\hline Samordning & Med andre erstatnings-, trygde- og forsikringsytelser \\
\hline Sikkerhet for ytelse & Legemiddelforsikringens betalingsevne \\
\hline Skatt & Skatt på tapt inntekt, ikke skatt på tapt fremtidig inntekt \\
\hline
\end{tabular}

Pasientskadeerstatningen

\begin{tabular}{|l|l|}
\hline Systematiseringskriterier & Beskrivelse \\
\hline Erstatningsområde & Personskade som følge av behandling i helseinstitusjon \\
\hline Ytelsespliktig & Norsk Pasientskadeerstatning eller forsikringsselskap \\
\hline Kriterier for ansvar & Lidt tap på grunn av pasientskade \\
\hline Utmåling / ytelsens karakter & Tapt inntekt, tap i fremtidig inntekt / engangsytelse \\
\hline Reduksjon/bortfall & Medvirkning jf. skl § 5-1 og lempning jf. skl § 5-2 \\
\hline Samordning & Med andre erstatnings-, trygde- og forsikringsytelser \\
\hline Sikkerhet for ytelse & Statsgarantert (NPS) eller forsikringsselskaps betalingsevne \\
\hline Skatt & Skatt på tapt inntekt, ikke skatt på tapt fremtidig inntekt \\
\hline
\end{tabular}




\section{Betydningen av arbeidsuførhetens opprinnelse}

\subsection{Problemstilling og disposisjon}

I dette kapittel vil jeg analyse og drøfte hvilken betydning uførhetens opprinnelse har for skadelidtes rett til erstatning. Jeg vil benytte tre forskjellige perspektiver i dette arbeidet.

Først vil jeg rette fokus mot hvilke mulige erstatningsgrunnlag en arbeidsufør kan gjøre gjeldende ut fra situasjonstypen uførheten har sin opprinnelse fra. Denne betraktningsmåten betegner jeg som et situasjonsorienterte perspektiv. Innfallsvinkelen bygger på de tabellariske fremstillinger i kapittel 2 .

Deretter vil jeg betrakte opprinnelsesspørsmålet fra en vinkel som jeg har kalt det ansvarsorienterte perspektiv. Denne betraktningsmåten går ut på å se arbeidsuføres kompensasjonsmuligheter i forhold til hvem som er ansvarlig for hendelser som utløser uførhet. Fremstillingen bygger på modellen som ble presentert i figur 2, 3, og 4.

Til slutt tar jeg for meg hvordan de forskjellige utmålingsregler, som varierer med opprinnelsen, får betydning for den arbeidsuføres kompensasjon. Denne måten å betrakte betydningen av arbeidsuførhetens opprinnelse på, har jeg kalt et ytelsesorientert perspektiv. Også dette perspektivet bygger på den tabellariske fremstilling av systematiseringsvariablene i kapittel 2.

\subsection{Det situasjonsorienterte perspektiv}

I dette perspektivet er det situasjonen, eller den sammenheng hvor uførheten oppstår, som står i fokus. Enkelte grunnlag har ingen bestemte type-situasjoner å dekke, og kan være aktuelle i en rekke forskjellige sammenhenger. Andre grunnlag dekker flere forskjellige situasjoner innenfor et begrenset område. Atter andre grunnlag dekker bare helt bestemte 
hendelser. Av tabellmaterialet i kapittel 2 fremgår dekningsomfanget for det enkelte grunnlag under systematiseringskriteriet erstatningsområde.

I det følgende behandles hvert av de tre erstatningsområdene skadeserstatning, trygd og forsikring med hensyn på dette perspektivet.

\subsubsection{Skadeserstatning}

Culpaansvaret og det ulovfestede objektive ansvaret dekker i utgangspunktet hendelser på alle livsområder. Felles for disse grunnlagene er at de forholder seg til om det har oppstått et dekningsberettiget tap, uten å stille krav til situasjonstypen. ${ }^{81}$

De øvrige grunnlag innen skadeserstatningsretten som har betydning for arbeidsuførhet, har alle snevrere dekningsområde og er lovfestede objektive grunnlag. Dette gjelder bilansvaret, produktansvaret, legemiddelansvaret, arbeidsgiveransvaret, pasientskadeansvaret og voldsoffererstatning. ${ }^{82}$ Felles for disse grunnlag er at de henspeiler på spesielle situasjonstyper som en skadevoldende hendelse kan oppstå innenfor.

I figur 6 har jeg fremstilt sammenhengen mellom de forskjellige grunnlagene for skadeserstatning.

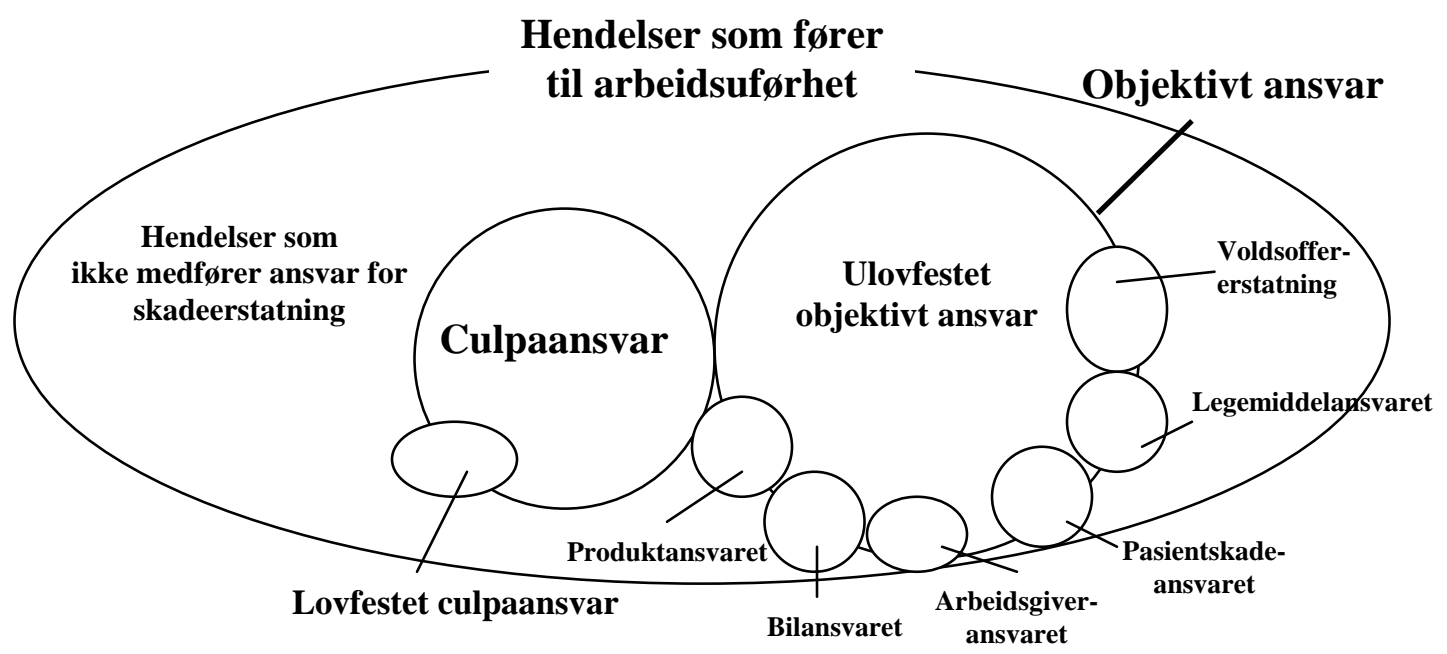

Figur 6: Sammenhengen i dekningsomfanget innenfor skadeserstatning

\footnotetext{
${ }^{81}$ Se punkt 2.2.2 og 2.2.3.
}

${ }^{82}$ Se nærmere punkt 2.2.4. 
Utgangspunktet er alle mulige hendelser som fører til arbeidsuførhet. Av disse hendelsene vil størstedelen ikke være dekket av et skadeserstatningsgrunnlag. Noen hendelser vil imidlertid være dekket, gjennom culpaansvaret og objektivt ansvar.

Innenfor culpaansvaret vil grunnlaget normalt være ulovfestet. Men enkelte hendelser vil være dekket av lovfestet culpaansvar. Dette kan være både være lovfesting av hendelser under det ulovfestede culpaansvaret, og hendelser som går utenom.

Innenfor det objektive ansvaret, vil enkelte spesielle situasjoner være dekket av lovfestede ansvarsgrunnlag. Øvrige situasjoner under objektivt ansvar vil være dekket av det ulovfestede ansvarsgrunnlag.

For en skadelidt vil det kunne fortone seg som et trappesystem, hvor erstatningsmulighetene på sett og vis bedres for hvert trinn. Det vil for en skadelidts del være fordelaktig å kunne plassere ansvaret høyest mulig i denne trappen. Dette er illustrert i figur 6.

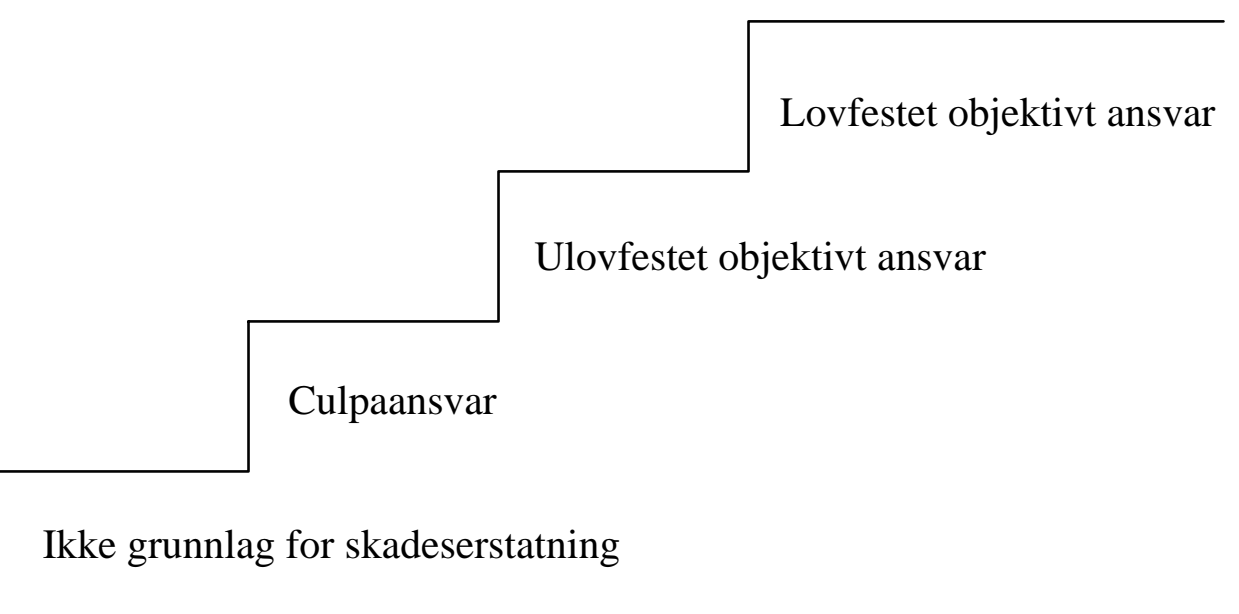

Figur 6: Sammenhengen mellom de forskjellige grunnlags omfang i erstatningsretten

Første trinn er de situasjoner hvor det ikke finnes grunnlag for skadeerstatning, selv om arbeidsuførhet har oppstått. 
Dernest kommer de culpasituasjonene hvor erstatning er aktuelt når skadevolder har opptrådt tilstrekkelig uaktsomt. Her er det nødvendig å få fastslått at skadevolder virkelig har opptrådt uaktsomt, noe som skadevolder ofte har all grunn til å bestride. Av denne grunn kan det være arbeidskrevende å utnytte dette grunnlag.

Videre er tredje trinn de ulovfestede objektive erstatningsreglene, som i utgangspunktet gir rett til erstatning uavhengig av skadevolders skyld. Dette grunnlaget favner følgelig bredere. Reglene er imidlertid ofte uklare på dette området, noe som fører til økt risiko og ofte bruk av tid og penger i rettsapparatet. En annen begrensning på begge de to sistnevnte nivåene er at man normalt er avhengig av skadevolders soliditet for å få nytte av sin rett til erstatning.

Trinn fire er de lovfestede objektive erstatningsreglene. Her gis den skadelidte rett til erstatning i situasjoner som er spesifisert i lovs form. Her er for det første rettsreglene normalt klarere enn på de lavere nivåene. Videre er skadelidte ofte sikret gjennom obligatoriske forsikringsdekninger og ordninger som sikrer erstatning selv om forsikringsplikten ikke oppfylles. Her kan den skadelidte gå direkte på forsikringsselskapet. Unntak er arbeidsgiveransvaret og produktansvaret, men disse grunnlagene er likevel ofte dekket av bedriftens frivillige forsikringer.

Sett fra den uføres side, vil altså sammenhengen som den uføreskapende hendelsen oppstår i, være av stor betydning for om det finnes grunnlag for skadeserstatning. En hendelse vil kunne være fullt erstatningsberettiget om den oppstår for eksempel i arbeid, mens en tilsvarende hendelse som skjer utenfor arbeid, kan være uberettiget skadeserstatning. Det er "trappenivået” for det livsområdet hendelsen kan innplasseres på, som er avgjørende for om det foreligger ansvarsgrunnlag, og hvilket ansvarsgrunnlag som kan gjøres gjeldende.

Når et tilfelle av arbeidsuførhet har inntruffet, vil det være tilfeldighetene som avgjør om den uføre har rett til skadeserstatning. Det enkelte skadeserstatningsgrunnlag yter imidlertid langt fra tilfeldig. Hvert grunnlag har sin historie og er bygget på velmenende hensyn. Det er uførheten som rammer mer eller mindre tilfeldig. Men for den arbeidsuføre er det liten trøst i at skaden hadde vært erstatningsberettiget om situasjonen hadde vært annerledes. For en fotgjenger som blir påkjørt under kryssing av en vei og dermed arbeidsufør, er tapet like stort enten påkjørselen skyldes en bil eller en sykkel. I 
erstatningssammenheng vil imidlertid forskjellen kunne bety ingen eller full tapserstatning. Reparasjonsmotivet ser med andre ord ikke ut til å være konsekvent vektlagt i skadeserstatningsretten. Jeg kommer tilbake til dette i kapittel 5.

\subsubsection{Trygd}

Trygderettens grunnlag for ytelser ved arbeidsuførhet er enklere å forholde seg til. De to grunnlagene som er aktuelle i denne sammenheng, er ordinær uførepensjon og uførepensjon ved yrkesskade.

Førstnevnte grunnlag har den egenskapen at det gir rett på ytelser ved arbeidsuførhet uavhengig av hva som har medført uførheten. Det som kreves er at visse kriterier ved helsetilstanden og medlemskap i folketrygden er oppfylt.

Det har altså ingen betydning hvilket rettsområde uførheten har sin opprinnelse fra. Man står her overfor en erstatningsytelse som er universell med hensyn til opprinnelse. Dette gjør uførepensjonen egnet i forhold til sitt formål, nemlig å skape økonomisk trygghet for den enkelte.

Uførepensjonen har altså en dekningsprofil som er forutsigbar. Den enkelte kan, med få unntak, forutsette at denne ytelsen vil komme til utbetaling ved uførhet, og kan innrette seg etter det.

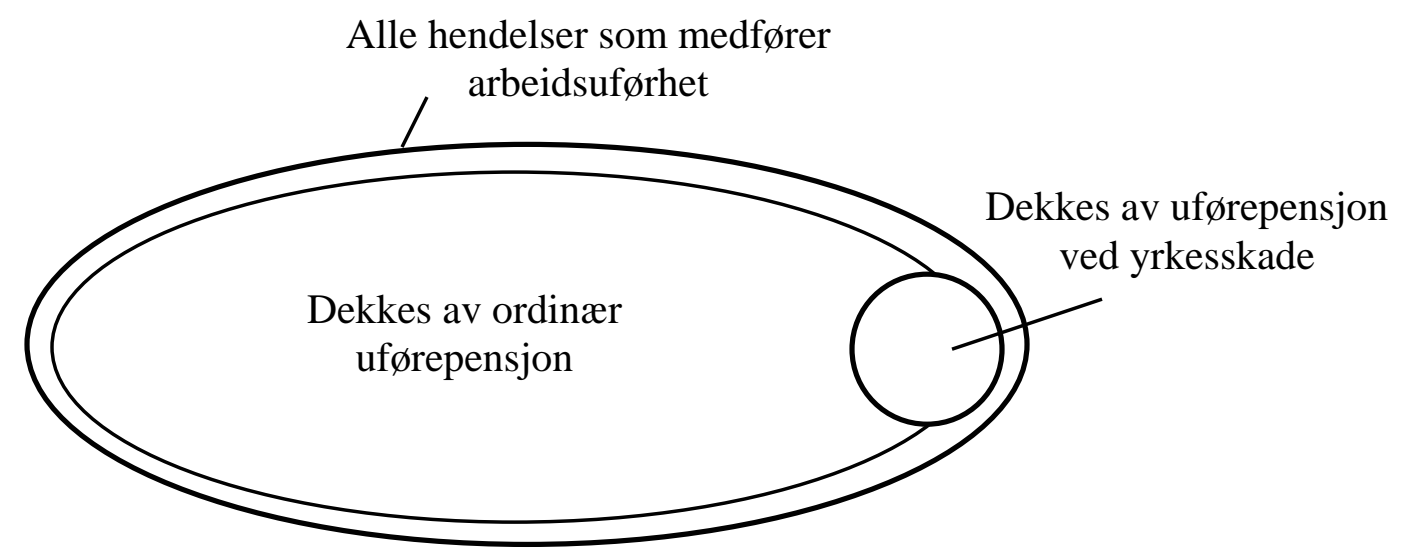

Figur 8: Sammenhengen av dekningsomfang i trygderetten 
Dekningsområdet for uførepensjon ved yrkesskade avviker fra den ordinære uførepensjon. For det første er det bare uføretilfeller som følge av arbeidsulykke som er dekket. For det andre er det enkelte situasjoner som dekkes ved yrkesskade som ikke dekkes av ordinær uførepensjon. Dette er når uføregraden er mellom 30 og 50 prosent og når de ordinære regler for medlemstid og fortsatt medlemskap ikke er oppfylt. Uførepensjon ved yrkesskade utgjør en liten kjerne i den ordinære uførepensjon, men har til en viss grad også har rekkevidde utover dette.

I figur 8 illustreres sammenhengen mellom folketrygdens ordinære uførepensjon og uførepensjon ved yrkesskade. Av alle tilfeller av arbeidsuførhet vil de fleste være dekket av den ordinære uførepensjon. Uførepensjon ved yrkesskade dekker bare en liten del av disse tilfellene, men også noen situasjoner som den ordinære uførepensjon ikke dekker.

Man kan her benytte en trappemodell for å vise betydningen av uførhetens opphav. Dette er vist i figur 9.

Uførepensjon ved yrkesskade

Ordinær uførepensjon

Figur 9: Sammenhengen mellom de ordinær uførepensjon og uførepensjon ved yrkesskade

Hvis man forutsetter at kriteriene for uførepensjon er oppfylt, vil erstatningsgrunnlaget i utgangspunktet være uførepensjon. Dersom øvrige kriterier er oppfylt vil skadelidte kunne få rett til en bedre dekning, altså yrkesskadetrygd.

Det kan imidlertid oppstå situasjoner hvor den uføre som følge av bl.a. kort trygdetid ikke har rett på uførepensjon. I slike tilfeller vil yrkesskadetrygden likevel kunne gi rett til ytelser. Det vil da være av stor betydning å få karakterisert den uføreskapende hendelsen som en arbeidsulykke. 


\subsubsection{Forsikring}

Forsikringsretten har, på samme måte som erstatningsretten, grunnlag som dekker generelt og grunnlag som dekker smalere områder. Forsikringsdekninger etableres vanligvis gjennom avtale mellom forsikringstaker og forsikringsselskap. Derfor er omfanget av dekningsområdet først og fremst avhengig av hva som er avtalt. Forsikringsavtaler og -vilkår er imidlertid nesten alltid standardiserte, slik at dekningsomfanget stort sett er det samme fra avtale til avtale. I tillegg vil dekningsomfanget enkelte ganger være fastsatt gjennom lov eller forskrift. ${ }^{83}$

\section{Personforsikring}

På personforsikringens område vil ytelsenes nedslagsfelt ha store likheter med de tidligere omtalte trygdeytelser ved arbeidsuførhet. Både uførerente og uførekapital dekkes i utgangspunktet uavhengig av hvor uførheten har sin opprinnelse. Det finnes imidlertid en rekke unntak.

Til forskjell fra trygdeytelser kan forsikringsytelser reduseres eller bortfalle som følge av at uførheten er fremkalt uaktsomt eller forsettelig. Også uførhet som følge av utøvelse av enkelte aktiviteter eller opphold på spesielle steder er utelukket som erstatningsgrunnlag. ${ }^{84}$ Eksempler på dette er dykking og opphold i krigsområder. I tillegg kan det være tatt forbehold i forsikringsavtalen. Samtlige begrensninger er imidlertid av en slik karakter at den forsikrede selv kan velge å holde seg innenfor disse. Dette fører til forutsigbarhet.

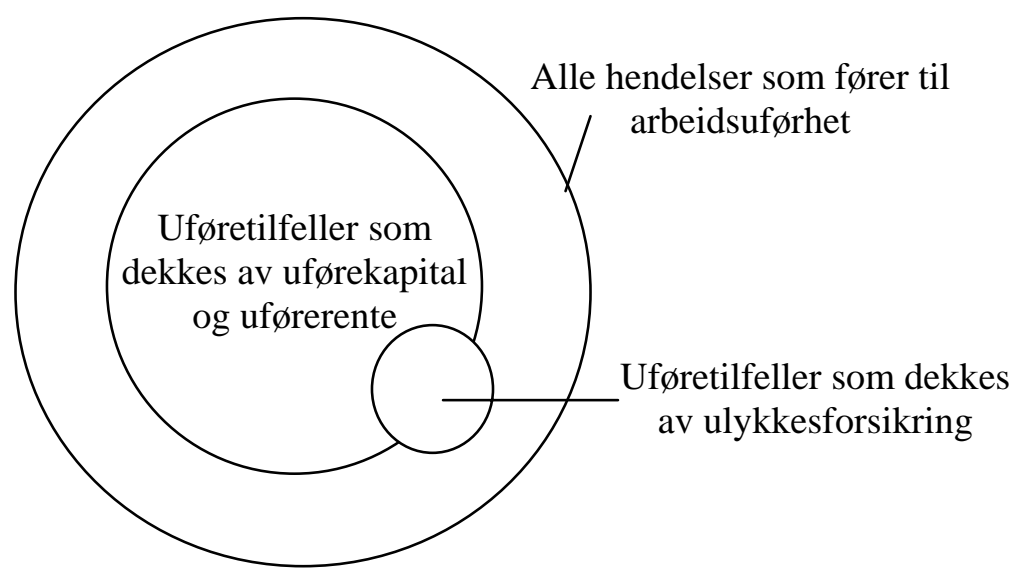

Figur 10: Sammenheng i dekningsomfang for personforsikring

\footnotetext{
${ }^{83}$ Se nærmere avsnitt 2.4.1.
}

${ }^{84}$ Se avsnitt 2.4.2. 
Ulykkesforsikring har i stor grad den samme oppbygning som uførekapital, men med den viktige forskjell at uførebegrepet relateres til medisinsk uførhet og ikke til arbeidsuførhet. Det betyr at skadelidte kan ha rett til ytelser fra dette grunnlag selv om arbeidsuførhet ikke er en følge. På den annen side dekkes bare ulykkeshendelser.

Sammenhengen mellom dekningsområdene innenfor personforsikring er illustrert i figur 10 .

\section{Ansvarsforsikring}

Ansvarsforsikringer etableres på grunnlag av forsikringstagers betraktninger av risiko og økonomisk handlefrihet. Ofte er det slik at ansvarsforsikring følger med som en del av hus-, innbo- og bedriftsforsikringer. Hensikten med slike forsikringer er vanligvis å dekke et uspesifisert, eller generelt, erstatningsansvar. Dekningsomfanget er dermed alle erstatningsskapende hendelser med unntak av de som faller utenfor grunnet begrensninger i forsikringsavtale og vilkår etter skadeserstatningslovens regler. ${ }^{85}$

I andre sammenhenger ønsker en potensiell skadevolder å dekke sitt ansvar på spesielle områder. Bakgrunnen kan være at vedkommende anser sitt skadepotensial som spesielt stort. Et eksempel på dette kan være eier av en rask båt som ønsker å redusere sitt erstatningsansvar hvis båten skulle påfører andre skade. Et annet er ønsket om å dekke en mulig erstatningsplikt som følge av produktansvaret.

Grunnen til at ansvarsforsikringer etableres, er for å sikre den potensielle skadevolder, og ikke den skadelidte. Dette gjelder selv om det er den skadelidte som får ytelser fra dekningen. Valg av om dekning skal etableres, og i så fall hva slags, vil derfor baseres på hva som er opportunt for skadevolder og ikke den skadelidte.

\section{"No-fault"-forsikringer}

"No-fault"-forsikringene er i oppbygning like ansvarsforsikringene. For "no-fault"dekningene som behandles her, ligger forskjellen i at det ikke er valgfritt når de skal etableres og hvordan de skal være utformet. På denne måten er det først og fremst hensynet til skadelidte som settes i fokus. Det bestemmes med andre ord hvilken sikkerhet

\footnotetext{
${ }^{85}$ Se avsnitt 2.4.3.
} 
potensielle skadelidte skal ha. Ansvaret med å dekke dette inn legges på skadevolder. I disse tilfellene er forsikringsplikten kombinert med sikringsordninger. Det er da grunnlag for ytelser selv om skadevolder er ukjent eller ikke har fulgt sin forsikringsplikt. ${ }^{86}$

”No-fault”-dekningene som blir behandlet i denne oppgaven, har nær tilknytning til erstatningsretten. De aktuelle forsikringsdekninger motsvarer et lovbestemt objektivt erstatningsansvar. Det er derfor egentlig en smakssak om man skal plassere grunnlagene i skadeserstatningsretten eller i forsikringsretten.

”No-fault”-forsikringene som behandles i denne sammenheng gir en dekning på hvert sitt avgrensede område. Følgelig er det bare en del av de totale hendelser som kommer inn under disse grunnlagene. Men innenfor grunnlagene er skadelidtes rettigheter mer omfattende enn for ordinære ansvarsforsikringer. For det første er det ikke et krav at skadevolder må ha opptrådt klanderverdig for at erstatningsplikt skal oppstå.

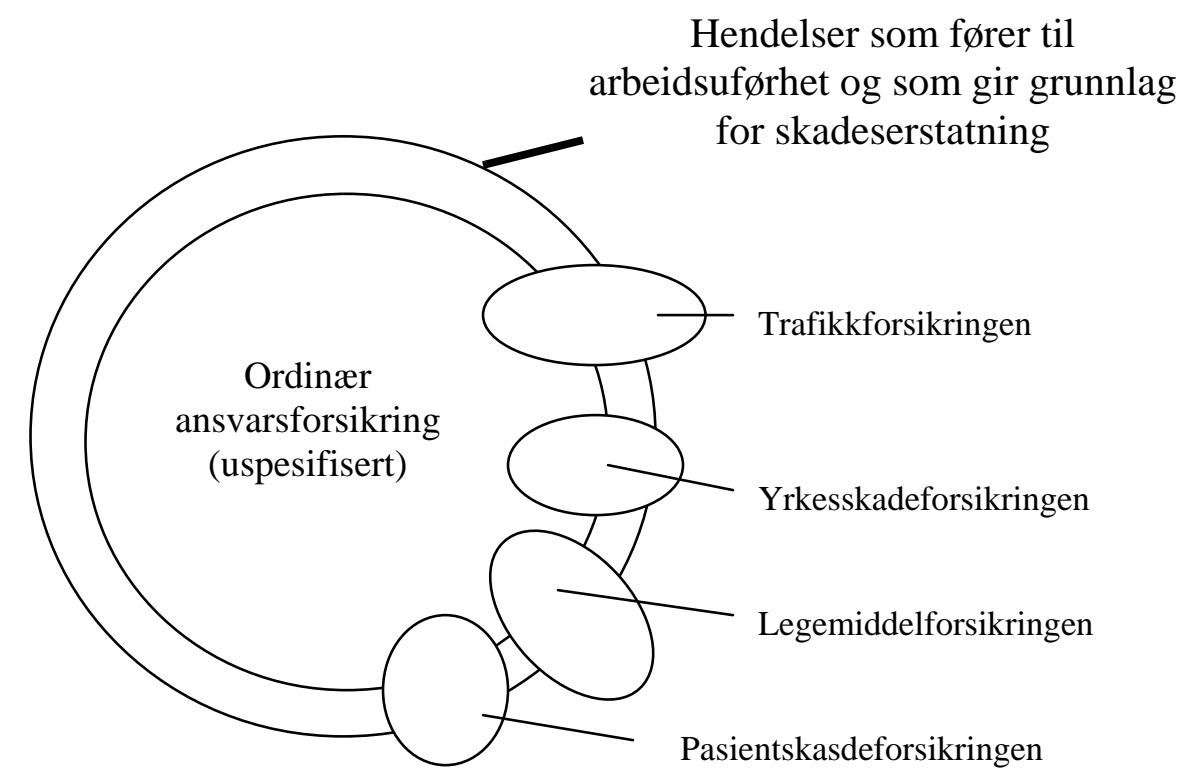

Figur 11: Sammenhengen mellom forskjellige typer ansvarsforsikringer

For det andre er det, som nevnt ovenfor, ikke avgjørende om skadevolder har etablert forsikring. Tilfellene som faller utenfor, følger av de ordinære lempningsreglene i skadeserstatningsloven.

\footnotetext{
${ }^{86}$ Jf. avsnitt 2.3.4.
} 
Sammenhengen mellom dekningsomfang i skadeserstatningsretten, ordinære ansvarsforsikringer med generell dekning og enkelte "no-fault"-forsikringene, er illustrert i figur 11.

Av alle tilfeller av erstatningsberettiget arbeidsuførhet som kommer inn under et grunnlag for skadeserstatning, vil en stor del kunne være dekket av ordinær ansvarsforsikring, men ikke alle. Utvalgte "no-fault”-forsikringer vil kunne dekke på tvers av dette. For det første vil de kunne dekke situasjoner som dekkes av både skadeserstatningsgrunnlag og ordinær ansvarsforsikring. For det andre kan disse dekke situasjoner som er dekket av skadeserstatningsgrunnlag og ikke av ansvarsforsikring. For det tredje vil de kunne dekke situasjoner som ikke dekkes av verken skadeserstatningsretten eller ansvarsforsikring.

Det er nærliggende å si at den enkelte kan sikre seg tilstrekkelig gjennom personforsikringer til at et hvilket som helst tap, som følge av arbeidsuførhet, blir dekket inn. Den enkelte forsikringstaker fastsetter på etableringstidspunktet, og innenfor visse grenser, hvilket erstatningsbeløp som skal ytes dersom arbeidsuførhet inntreffer. Denne tankegangen gir et rasjonelt individ mulighet til å eliminere mye av risikoen for økonomisk tap som følge av arbeidsuførhet.

Det finnes imidlertid flere begrensende elementer i dette resonnementet. For det første trenger den enkelte tilstrekkelig kunnskap om sine rettigheter innen flere forskjellige rettsområder. Dette vil mange ikke ha eller mangle evne til å skaffe seg. For det andre, om man ser sitt behov, er det ikke sikkert at man kan finne et forsikringsselskap som er villig til å ta på seg risikoen for eksempel på grunn av forsikringssøkerens dårlige helse. For det tredje kan prisen for risikoavlastningen bli så høy at den enkelte ikke kan eller er villig til å betale.

For ordinære ansvarsforsikringer er det opp til den potensielle skadevolder å dekke seg inn. For en skadelidt vil dette i utgangspunktet ikke ha vesentlig betydning. Ansvarsforsikringen dekker ikke mer enn det som kan gjøres gjeldende etter skadeserstatningsretten. Likevel vil skadelidtes betalingsevne og -vilje kunne utgjøre en betydelig forskjell for skadelidte. 
Når det gjelder "no-fault”-forsikringer, er det i denne sammenheng, verken skadevolder eller skadelidte som avgjør om forsikringsdekning skal etableres. Det er lovbestemt, og det er også dekningsomfanget. For den skadelidte vil denne type forsikring fortone seg som en kostnadsfri personforsikring på et avgrenset område, og er følgelig et gode. Men for den risikouvillige bør ikke slike dekninger ha stor betydning. En potensiell skadelidt må likevel etablere forsikringsdekninger for å dekke inn alle andre mulige hendelser. Følgelig vil slike forsikringer ha betydning for den som er villig til å ta sjanser og den som ikke evner å dekke inn sitt forsikringsbehov på annen måte.

\section{Oppsummering}

Ved å betrakte de tre erstatningsområdene skadeserstatning, trygd og forsikring samtidig, får man en sammenheng som vist i figur 12. Enhver situasjon hvor arbeidsuførhet inntreffer vil være erstatningsmessig dekket av ingen, ett, to eller tre av disse områdene. Hvor mange av områdene som vil bidra i den enkelte situasjon, og hva slags grunnlag som kommer til anvendelse, vil variere fra situasjon til situasjon.

For de fleste vil dette fremstå som uoversiktlig. Det vil også ofte kunne fremstå som tilfeldig hvilke erstatningsgrunnlag som kan gjøres gjeldende.

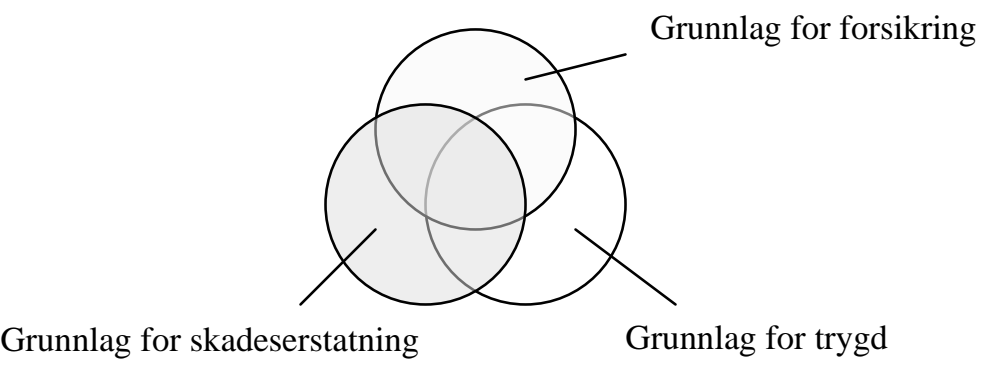

Figur 12: Erstatningsområdene i sammenheng 


\subsection{Det ansvarsorienterte perspektiv}

Som vi her skal se, har plassering av ansvar betydning for den skadelidtes muligheter for kompensasjon som følge av arbeidsuførhet. Fra den skadelidtes synsvinkel er tapet, som tidligere påpekt, like stort uavhengig av hva som har forårsaket dette. På samme måte fremstår tapet like inngripende uavhengig av hvem som er ansvarlig for det.

Innfallsvinkelen i denne delen har sitt utspring i modellene som er presentert i figur 2, 3 og 4. Forøvrig legges den systematiserte fremstillingen i kapittel 2 til grunn.

Modellen som benyttes til å forklare sammenhengene, tar utgangspunkt i alle mulige tilfeller av sykdom og skade som fører til at arbeidsuførhet oppstår. Disse tilfeller deles inn i tre grupper i forhold til hvem som er ansvarlig, hhv. ingen, skadelidte selv og andre. Videre blir disse ”ansvarsgruppene” betraktet i forhold til hvert av de tre rettsområdene skadeserstatning, trygd og forsikring. Man står nå med ni forskjellige kombinasjoner av ansvarlig/rettsområde. Dette er vist i figur 13.

\begin{tabular}{c|c|c|c|c} 
& $\begin{array}{c}\text { Skades- } \\
\text { erstatning }\end{array}$ & Trygd & Forsikring & \\
\hline $\begin{array}{c}\text { Ansvarlig: } \\
\text { ingen }\end{array}$ & & & & \\
\hline $\begin{array}{c}\text { Ansvarlig: } \\
\text { skadelidte selv }\end{array}$ & & & & \\
\hline $\begin{array}{c}\text { Ansvarlig: } \\
\text { andre }\end{array}$ & & & & \\
\hline
\end{tabular}

Figur 13: Kombinasjoner av ansvar og rettsområde

For å få et enda bedre grunnlag for den videre analyse splittes hvert av de tre rettsområdene videre opp i hovedgrupper av erstatningsgrunnlag. Erstatningsretten deles inn i culpaansvar, ulovfestet objektivt ansvar og lovfestet objektivt ansvar osv. Denne oppdelingen er skjematisk fremstilt i figur 14. 


\begin{tabular}{|l|c|c|c|c|c|c|c|c|}
\cline { 2 - 9 } \multicolumn{1}{c|}{} & \multicolumn{3}{c|}{ Skadeserstatning } & \multicolumn{2}{c|}{ Trygd } & \multicolumn{3}{c|}{ Forsikring } \\
\cline { 2 - 9 } & $\begin{array}{c}\text { Culpa- } \\
\text { ansvar }\end{array}$ & $\begin{array}{c}\text { Ulovf. obj. } \\
\text { Ansvar }\end{array}$ & $\begin{array}{c}\text { Lovf. obj. } \\
\text { ansvar }\end{array}$ & $\begin{array}{c}\text { Ordinær } \\
\text { uførepensjon }\end{array}$ & $\begin{array}{c}\text { Uførepensjon } \\
\text { Yrkesskade }\end{array}$ & $\begin{array}{c}\text { Person- } \\
\text { forsikring }\end{array}$ & $\begin{array}{c}\text { Ansvars- } \\
\text { forsikring }\end{array}$ & $\begin{array}{c}\text { "no-fault"- } \\
\text { forsikring }\end{array}$ \\
\hline Ansvarlig: ingen & & & & $\mathbf{x}$ & $\mathbf{x}$ & $\mathbf{x}$ & & $\mathbf{x}$ \\
\hline Ansvarlig: selv & & & & $\mathbf{x}$ & $\mathbf{x}$ & $\mathbf{x}$ & & \\
\hline Ansvarlig: andre & $\mathbf{x}$ & $\mathbf{x}$ & $\mathbf{x}$ & $\mathbf{x}$ & $\mathbf{x}$ & $\mathbf{x}$ & $\mathbf{x}$ & $\mathbf{x}$ \\
\hline
\end{tabular}

Figur 14: De forskjellige grunnlag fremstilt i forhold til ansvar

Figur 14 er formet som en tabell. Tabellen viser hvilke ansvarsgrunnlag som kan være aktuelle for forskjellige plasseringer av ansvar (markert med x).

Ved å inndele de skadevoldende hendelser etter dette mønster kan man lettere belyse betydningen av hvor ansvaret plasseres, og dermed betydningen av tapets opprinnelse.

Det er nå mulig å analysere hver enkel kombinasjon av ansvar (for en uføreskapende hendelse) og ansvarsgrunnlag i forhold til om den kan gjøres gjeldende.

Det mest fremtredende trekk ved oppstillingen er at hendelser, som andre har ansvar for kan føre til erstatningsplikt under samtlige ansvarsgrunnlag. Hvor skadelidte selv er ansvarlig eller hvor ingen er ansvarlig, er det betydelig mindre mulighet for kompensasjon.

Et "selvfølgelig” trekk er at hendelser som skadelidte selv eller ingen er ansvarlige for, ikke kommer inn under grunnlagene for skadeserstatning.

Videre ser man at det er et karakteristisk trekk ved trygdeytelser at disse kommer til utbetaling uavhengig av hvem som sitter med ansvaret for den uføreskapende hendelsen. Dette gjeldet også for personforsikringenes del.

For øvrig kan man observere at skadeserstatningretten har lavest dekningsomfang når man betrakter alle situasjoner samlet, mens trygderetten har fullt dekningsomfang.

Man ser altså at det kan være av stor betydning for den arbeidsuføre hvem som er ansvarlig for den uføreskapende hendelsen. 
Ved å betrakte retten fra dette perspektivet, fremstår reglene i hovedtrekk som logiske og forutsigbare. Det er ikke rimelig at andre skal betale erstatning for hendelser som skadelidte selv eller ingen er ansvarlige for. Det er derimot rimelig at folketrygden dekker alle hendelser på bakgrunn av dens formål som er å skape økonomisk trygghet for alle, uansett hendelsesforløp. Det er også naturlig at personforsikringsdekningene, som den enkelte selv betaler, dekker på alle områder.

Ovennevnte analyse gir klare signaler om at det for den skadelidtes del er fordelaktig om ansvaret kan plasseres på andre, enten det er privatpersoner eller virksomheter. En naturlig følge er at den enkelte skadelidte får et incitament til å forsøke å skyve ansvaret over på andre, dersom det er mulig. Et eksempel på en slik mulighet er yrkesskadeforsikringsloven av 16. juni 1989 nr. 65, som i § 5 har regler om når en yrkesskade skal anses konstatert. Konstateringstidspunktet er i neste omgang avgjørende for hvem et erstatningskrav kan rettes mot. F.eks kan en håndverker som driver selvstendig virksomhet og har pådratt seg en skade, ved å skaffe seg en arbeidsgiver, ha mulighet til å overføre tapet på arbeidsgivers forsikringsselskap.

\subsection{Det ytelsesorienterte perspektiv}

I dette punkt skal jeg se på hvordan de forskjellige erstatningsytelsers form og omfang innvirker på kompensasjon av tap som følge av arbeidsuførhet.

I de tabellariske sammendragene i kapittel 2, beskrives ett av systematiseringskriteriene som ytelsenes utmåling og karakter. Den følgende analyse bygger på disse data.

Alle skadeserstatningsgrunnlag skal i de sammenhenger som er av interesse her, dekke tapt inntekt og tap i fremtidig inntekt. Skadelidte vil derfor i utgangspunktet kunne regne med full erstatning for arbeidsuførhet som kommer inn under et av disse grunnlagene.

Utmålingen av skadeserstatning vil imidlertid i stor grad baseres på antakelser om bl.a. fremtidige inntekter og utgifter, og normalt tilmåles ytelsene som engangsbeløp. Dersom 
antakelsene viser seg å være feilaktige, vil ikke intensjonen om full erstatning bli oppfylt. ${ }^{87}$ Men under forutsetning av rett utmåling kan man si at hvis man har rett til skadeserstatning, vil man som hovedregel få full kompensasjon.

Trygdeytelsenes utmåling er bestemt i folketrygdloven. Ytelsene følger en forholdsvis komplisert utregningsmåte. Ved en normalinntekt vil uførepensjonens størrelse som en tommelfingerregel ligge på omtrent halvparten av den bortfalte lønnsinntekt. ${ }^{88}$ Uførepensjon ved yrkesskade baseres på samme utregningsmetode, men har visse særtrekk som normalt gjør ytelsene noe større.

Folketrygden har som formål å gi en grunndekning, som skal gi den uføre et minimum av levestandard. Det er altså her ikke meningen å gi full kompensasjon for det oppståtte tap. ${ }^{89}$

Utmålingen av personforsikringsytelser gjøres etter det avtalte forsikringsbeløp.

Utfordringen for den forsikrede er, foruten å se sitt behov for forsikringsdekning, å sette forsikringssummen tilstrekkelig høyt. Fra dette hold får man det man betaler for.

For ansvarsforsikringene og "no-fault”-forsikringene følger samme utmålingsprinsipp som for skadeserstatning.

Sett fra denne vinkel er det klart at den enkelte normalt kan etablere forsikringsdekninger som gjør den totale ytelse mer forutsigbar. Hvordan den enkelte velger å tilpasse seg, vil likevel være et produkt av økonomiske betraktninger, risikovurderinger og evne og vilje til å foreta slike betraktninger.

Erstatningsytelsenes utmålingsregler varierer altså mellom de enkelte erstatningsgrunnlag. Denne forskjellen medfører at det kan få stor betydning for den uføre, ikke bare om det foreligger erstatningsgrunnlag, men også hvilket grunnlag som foreligger.

\footnotetext{
${ }^{87}$ Se avsnitt 2.2.1.

${ }^{88}$ Trygdeetaten, Pensjonskalkulator, www.trygdeeataten.no.

${ }^{89}$ Se avsnitt 2.3.2 og 2.3.3.
} 


\section{Ytelsenes påvirkning av andre ytelser og øvrige omstendigheter}

\subsection{Problemstilling og disposisjon}

En rekke forskjellige omstendigheter påvirker ytelsene som følger av de forskjellige erstatningsgrunnlag. Dette kan være ytelser fra andre grunnlag eller øvrige omstendigheter. I det følgende søkes den tredje problemstillingen besvart.

Analysen og drøftelsen i dette kapittel blir foretatt ut fra fire perspektiver; samordning, skatt, sikkerhet for ytelse og reduksjon/bortfall. Alle perspektiver er benyttet som systematiseringskriterier i fremstillingen av bakgrunnsretten i kapittel 2.

\subsection{Samordning}

Jeg vil i det følgende benytte begrepet samordning som en fellesbetegnelse på å redusere en ytelse som følge av en annen. Regler om samordning finnes innenfor alle de tre rettsområdene, men de varierer i omfang.

Ved utmålingen av skadeserstatning skal det i flg. skadeserstatningsloven § 3-1 gjøres fradrag for trygdeytelser. Videre skal det tas hensyn til forsikringsytelser som den erstatningsansvarlige har betalt premien for, dvs. ansvarsforsikringer. I tillegg kan det tas hensyn til skadelidtes egne forsikringer, som her er personforsikringer. ${ }^{90}$

Utmålingsreglene for erstatningsytelser har altså en funksjon som motvirker overkompensasjon. Enkelte skadelidte vil nok oppfatte samordningen som et inngrep i egne rettigheter. Problematisk bør dette likevel ikke være hvis man blir stillet økonomisk likt som før. For samfunnets del vil det imidlertid fremstå som rimelig at ingen skal tjene på å bli arbeidsuføre. Samtidig minimeres den samlede ressursbruk.

\footnotetext{
${ }^{90}$ Se avsnitt 2.2.1.
} 
Utmålingen av trygdeytelser foretas i utgangspunktet uten fradrag for andre ytelser. Et unntak er pensjonslignende ytelser fra arbeidsgiver. ${ }^{91}$ Siden folketrygden ikke har ambisjoner om å yte full kompensasjon er det mindre behov for å begrense overkompensasjon.

Utmåling av forsikringsytelser gjøres, for personforsikringenes del, etter avtalt erstatningsbeløp. Dette beløpet avkortes ikke som følge av andre ytelser med mindre det er avtalt eller tatt inn i forsikringsavtale- og vilkår. ${ }^{92}$ Det er også det naturlige siden forsikringstaker selv betaler for ytelsen.

Utmåling av ansvarsforsikringer og "no-fault”-forsikringer følger samme prinsipper som utmålingen av skadeserstatning, og blir følgelig avkortet. ${ }^{93}$

I hovedtrekk kan man si at avkorting først blir foretatt når den totale ytelse overstiger tapet. Det er ikke alle ytelser som blir avkortet. I hvor stor grad overkompensasjon blir motvirket, avhenger av hva slags erstatningsytelser som fører til overkompensasjon.

\subsection{Skatt}

Kompensasjon ved arbeidsuførhet består i å overføre et pengebeløp fra en part til en annen. Overføringene bærer preg av å være inntekt på mottakerens hånd, og inntekt er normalt underlagt beskatning.

Det varierer imidlertid hvordan erstatningsytelser behandles skattemessig. For den erstatningsberettigede er det netto ytelse som kan disponeres. Følgelig vil det være av stor betydning hvordan ytelsene beskattes.

Ytelser etter grunnlag for skadeserstatning beskattes på varierende måte.

Voldsoffererstatning er helt fritatt for skatt. For de øvrige grunnlag for skadeserstatning belastes kompensasjon for tapt inntekt med inntektsskatt, mens tap i fremtidig inntekt ikke er underlagt beskatning. Skattebelastning blir det imidlertid tatt hensyn til i

\footnotetext{
${ }^{91}$ Se avsnitt 2.3.1

${ }^{92}$ Se avsnitt 2.4.1

93 Jf. avsnitt 2.4 .3 og 2.4 .4
} 
erstatningsutmålingen. ${ }^{94}$ Følgelig blir innvirkningen på det den skadelidte sitter igjen med, liten.

Trygdeytelser ved arbeidsuførhet har store likhetstrekk med den arbeidsinntekten som de kommer i stedet for, og beskattes på samme måte, altså som inntektsskatt. Trygdeytelsene, som fra før ikke gir full kompensasjon, blir ytterligere reduserte som følge av skattebelastningen. ${ }^{95}$ Gunstige regler om lav folketrygdavgift og særfradrag begrenser imidlertid skattebelastningen slik at dekningsgraden blir høyere.

Ytelser fra forsikringsdekninger er også i varierende grad underlagt beskatning. Hvis man ser bort fra ansvarsforsikringer, som følger skattereglene for skadeserstatning, kan man som hovedregel si at engangsytelser ikke beskattes, mens periodiske ytelser beskattes som inntekt. $^{96}$ Siden personforsikring er ytelser som den potensielle skadelidte etablerer, bestemmer størrelsen på og betaler for, er det ulogisk at ytelsen skal beskattes forskjellig avhengig av om den utbetales i en eller flere omganger. Det er imidlertid slik at hvis man er bevisst på dette, kan man eliminere forskjellen ved å tilpasse forsikringssummen.

Man kan stille seg undrende til hvorfor de forskjellige erstatningsytelser ikke er underlagt samme skatteregler. Forklaringen må ligge i at rettsområdene hver for seg har blitt utviklet påvirket av forskjellige mer eller mindre velbegrunnede hensyn.

Som en oppsummering kan man si at skattereglene kan ha varierende betydning for den arbeidsføre. Skadeserstatningens utmåling tar som nevnt hensyn til skatt, og forsikringstaker kan regulere forsikringssummer slik at de kompenserer for skattebelastningen. Betydningen av skatt i slike sammenhenger bør derfor være begrenset. Reduksjonen av ytelser fra folketrygden kan man imidlertid ikke påvirke. Så her vil man kunne få betydelig reduserte ytelser.

\subsection{Sikkerhet for ytelse}

Det er ikke tilstrekkelig at et erstatningsgrunnlag gir den arbeidsuføre rett til erstatning. Den uføre må også få overført ytelsen til seg. Uavhengig av om dette skjer frivillig eller

\footnotetext{
${ }^{94}$ Se avsnitt 2.2.1

${ }^{95}$ Jf. avsnitt 2.3.1
} 
med myndighetenes hjelp, er det helt avgjørende at den erstatningspliktige har tilstrekkelig yteevne.

I skadeserstatningssammenheng er det i utgangspunktet skadevolder som skal betale erstatning. Skadevolder kan være en privatperson eller en virksomhet. Det vil følgelig være avgjørende for skadelidte om skadevolder er tilstrekkelig økonomisk solid. ${ }^{97}$ Dette gjelder imidlertid ikke alltid.

Ofte vil skadevolders skadevoldende handlinger være dekket av ansvarsforsikring, enten ordinære eller "no-fault”-forsikringer. Soliditetsspørsmålet bli da skjøvet over på forsikringsselskapet. Og et forsikringsselskap er underlagt strenge regler for hvor stor risiko det kan påta seg i forhold til sin soliditet. ${ }^{98}$ Selv om det eksisterer en teoretisk risiko, kan man i praktisk henseende anse ytelser fra dette hold for sikre. Det samme gjelder for personforsikring.

Sikre er også ytelser fra folketrygden, med den norske stat som ansvarlig. Dette gjelder også voldsoffererstatning. Stortinget har imidlertid, innenfor grensene av grunnloven § 97, anledning til å endre trygderettigheter. ${ }^{99}$ Dette innebærer et visst usikkerhetsmoment.

De ansvarsgrunnlag som kan anses for å være usikre i denne sammenheng, er culpaansvaret, det ulovfestede objektive ansvar og arbeidsgiveransvaret. I disse sammenhenger vil det være en mulighet for at skadevolder ikke kan gjøre opp for seg og heller ikke er dekket av ansvarsforsikringer. I såfall må den arbeidsuføre bære denne delen av tapet selv.

\subsection{Reduksjon og bortfall}

En erstatningsytelse som i utgangspunktet er berettiget - kan, under visse omstendigheter reduseres eller falle bort.

\footnotetext{
${ }^{96}$ Se nærmere kapittel 2.4.1

${ }^{97}$ Se kapittel 2.2.1

98 Jf. kapittel 2.4.1

${ }^{99}$ Se nærmere kapittel 2.3.1
} 
I skadeserstatningssammenheng vil erstatningen kunne settes ned eller falle helt bort som følge av skadelidtes medvirkning, jf. skadeserstatningsloven $§ 5.1$.

I enkelte tilfeller kan skadelidte anses for å ha akseptert risikoen som handlingens skadeevne representerer. ${ }^{100}$ I slike tilfeller vil følgen være at det er skadelidte selv som må bære tapet. Læren om "aksept av risiko” har imidlertid stadig fått redusert sin betydning i erstatningsretten. Det er nå trolig bare i helt spesielle sammenhenger at dette prinsippet vil kunne slå gjennom. ${ }^{101}$

Videre vil ansvaret kunne lempes, jf. skadeserstatningsloven § 5-2. ${ }^{102}$

Ytelser på trygderettens område vil ikke falle bort som følge av den uføres medvirkning eller som følge av "aksept av risiko”. Ytelsen kan heller ikke lempes. Ytelsene fra denne kant kan imidlertid bortfalle som følge av at vilkårene for å motta ytelsen ikke lenger er oppfylt. $^{103}$

På forsikringsrettens område finnes det en rekke omstendigheter som kan føre til at erstatningsytelsen reduseres eller faller bort.

Personforsikringsytelser kan nedsettes eller falle bort ved forsømmelse av opplysningsplikt eller ved uaktsom eller forsettelig fremkalling av forsikringstilfellet. Dette følger av hhv. forsikringsavtaleloven $\S \S 13-2,13-8$ og 13-9. Videre kan periodiske ytelser falle bort hvis vilkårene ikke lenger er oppfylt. ${ }^{104}$

For "no-fault"-dekninger kan ytelsen reduseres eller bortfalle som følge av samme omstendigheter som ved skadeserstatning (omtalt over). Dette gjelder også for ansvarsforsikringer, men her gjelder ytterligere en begrensning; tilfeller hvor skadevolder, altså forsikringstaker, handler med forsett, jf. skadeserstatningsloven § 4-9.

\footnotetext{
${ }^{100}$ Peter Lødrup, Lærebok i erstatningsrett, Oslo 1999 s. 158-159.

${ }^{101}$ Se Asbjørn Kjønstad, Erstatningsretten i utvikling, Oslo 2003 s. 503-535.

${ }^{102}$ Se pun8kt 2.2.1.

${ }^{103}$ Se punkt 2.3.1.

${ }^{104}$ Se punkt 2.4.1.
} 
Bortfall av en erstatningsytelse vil kunne får alvorlige økonomiske konsekvenser for den uføre. Men siden de fleste begrensninger bygger på momenter som den skadelidte selv kan påvirke, vil slike reduksjoner sjelden fremstå som urimelige.

Enkelte reduksjonsmuligheter beror imidlertid i liten grad på skadelidte. Dette gjelder skadeserstatningslovens regler om lempning, hvor ansvaret kan bortfalle på bakgrunn av omstendigheter som skadelidte ikke kan påvirke. Det samme gjelder ansvarsforsikringens begrensning når skadevolder opptrer forsettelig. I forhold til ansvarsforsikring ender dette opp med å bli et spørsmål om skadevolders soliditet, siden ansvaret slår tilbake på denne part. 


\section{Hensynene bak kompensasjonsordningene}

\subsection{Problemstilling og disposisjon}

Det er tidligere vist at erstatningsmulighetene varierer mellom forskjellige situasjoner og mellom forskjellige livsområder. Dette kan trolig i stor grad forklares med at de ulike hensyn som ligger bak kompensasjonsgrunnlagene er vektlagt i varierende grad. Men hvilke hensyn er dette, og i hvor stor grad blir de ivaretatt?

Jeg vil i det følgende søke å belyse avhandlingens fjerde hovedproblemstilling. Dette gjøres ved å drøfte enkelte sider av ytelsesgrunnlagenes bakenforliggende hensyn. Først presenterer jeg hensynene, som også er omtalt i kapittel 2. Deretter drøfter jeg utvalgte spørsmål. Til slutt oppsummeres fremstillingen.

\subsection{De forskjellige hensyn}

Hensynet til reparasjon er et element i alle kompensasjonsordninger ved arbeidsuførhet. Ved bortfall av arbeidsevne, og dermed også arbeidsinntekt, oppstår et behov for reparasjon eller gjenoppretting. Det er den uføre, og andre som er avhengige av den uføres inntekt, som her settes i fokus.

Videre innehar flere av kompensasjonsordningene elementer av prevensjon. Ved å pålegge ansvar for erstatning, vil man kunne påvirke skadevoldende adferd. Også potensielle skadelidendes adferd vil kunne påvirkes ved å sette enkelte begrensninger i erstatningsretten.

Mange grunnlag for ytelser ved arbeidsuførhet flytter tapet, helt eller delvis, fra den uføre og over på andre. Tapet kan overføres på en eller flere ansvarlige skadevoldere, større grupper eller hele samfunnet. Hensynet som her gjør seg gjeldende er ønsket om optimal 
fordeling av kostnadene. Som eksempel fordeles trygdeytelser på folketrygdens medlemmer og forsikringsytelser på forsikringsfellesskapets medlemmer. En slik omfattende fordeling har også en pulveriseringseffekt.

De fleste kompensasjonsgrunnlag bygger også i større eller mindre grad på rettferdighetsog rimelighetshensyn. De fleste vil oppfatte det som rettferdig at en grovt uaktsom skadevolder må bære deler tapet som en uskyldig skadelidt har blitt påført. På samme måte oppfattes det normalt som rimelig at alle har rett til et minimum av ytelser fra folketrygden.

\subsection{Blir ytelsen brukt til reparasjon?}

Erstatningsytelsen som den arbeidsuføre får utmålt, skal hovedsakelig dekke fremtidig inntektstap. Det fremtidige inntektstap består av bortfall av periodisk inntekt. Sagt på en annen måte vil tapet, reelt sett, oppstå daglig som følge av dennes dags bortfalte arbeidsinntekt. Dette vil pågå så lenge arbeidsinntekten uteblir.

Erstatningsytelser utmåles vanligvis som engangsytelser. Trygdeytelser derimot, ytes periodisk. Forsikringsytelser fra renteforsikringer ytes også periodisk, mens øvrige ytelser som følge av forsikringsavtaler, overføres som engangsbeløp.

For mottakeren vil en periodisk ytelse som tilsvarer den periodiske bortfalte inntekt, altså tapet, ikke medføre endringer i den økonomiske situasjon. Man vil oppnå full reparasjon. Dette vil f.eks være mulig å få til med en kombinasjon av trygd og renteforsikring.

Det vanlige er imidlertid at skadeserstatning ytes som engangsbeløp. Kompensasjonen for det daglige, fremtidige inntektsbortfall ytes samlet og forskuddsvis. Dermed får mottakeren ansvaret for å disponere ytelsen slik at denne reparerer det periodiske bortfallet.

Mottakerens fordeling vil bero på dennes evne og vilje til å disponere pengene til sitt eget beste. En mulig måte å oppnå riktig periodisering på, er å plassere erstatningen hos et forsikringsselskap i livrente eller lignende. Her vil forsikringsselskapet sørge for forvaltningen av midlene og utbetaling av ytelsen i porsjoner. 
Det er likevel stor mulighet for at mottakeren av en erstatningsytelse forbruker denne raskere enn tapet påløper. Man kan lett å tenke seg til hvordan et pengebeløp på konto, ofte et millionbeløp, kan friste de fleste. En følge av dette er at ytelsen blir benyttet til overkompensasjon tidlig i tapsperioden på bekostning av inntektskompensasjon som ligger lenger frem i tid. Erstatningen vil dermed i større eller mindre grad ikke går til å reparere tap.

\subsection{Er reglene egnet til å "reparere" arbeidsuførhet i dagens samfunn?}

Trygdeetatens årbok 2003 presenterer bl.a. statistikk over uførepensjonister. Man ser en klart stigende trend i antall uføretilfeller totalt, og at kvinner utgjør størstedelen av økningen. ${ }^{105}$ Man ser også at uføretilfeller som følger av skader, vold og lignende utgjør ca 5\% av uføretilfellene. Av disse tilfellene utgjør kvinner ca 1/3.

Ca 2/3 av alle uføretilfeller skyldes psykiske lidelser og muskel/skjelettlidelser. Av disse utgjør kvinner 60\%.

Til forskjell fra tidligere er begge kjønn bortimot likt representert i arbeidslivet, mot tidligere en hovedvekt av menn. Dette har for det første ført til at flere er i arbeid, som igjen har ført til at flere blir eksponert for arbeidsrelaterte skader og sykdommer. For det andre har det ført til en vridning av uføreårsak fra det som er typisk for menn, og mot det som er mer typisk for kvinner.

Hvis man i første omgang fokuserer på skadeserstatningsretten, ser man at grunnlaget fra dette rettsområdet i stor grad dekker uføretilfeller som ligger innefor skader, vold og lignende, altså 5\% av tilfellene. Det er mer unntaksvis at skadeserstatningsretten gir grunnlag for ytelser som følge av andre årsaker, altså de øvrige 95\%.

Videre viser statistikken at årsakene til uførhet har hatt en klar tendens til å gå fra ulykkesopprinnelse til sykdomsopprinnelse. Som eksempel har arbeidsplasser og biler blitt sikrere, samtidig som livsstilsendringer fører til økt hyppighet av enkelte sykdommer som ikke har dekningsgrunnlag innen skadeserstatningsretten. Man ser her at

\footnotetext{
105 Trygdeetaten, Trygdeetatens årbok 2003 s. 121-146, www.trygdeetaten.no.
} 
skadeserstatningsgrunnlag, som i utgangspunktet har dekket en liten andel av de totale uføretilfeller, har hatt en tendens til stadig å dekke mindre.

Trygdeytelser gir rett på erstatning uavhengig av årsak og er derfor godt egnet i alle henseende. Trygdeytelsene er imidlertid for lave til å kompensere tapet alene. Men med hjelp av forsikringsdekninger kan man i utgangspunktet kompensere ethvert inntektstap. Denne oppgaven er imidlertid overlatt til den enkelte, og som tidligere omtalt, er dette ikke alltid heldig. Den enkelte må ha evne og vilje til å sette seg inn i økonomiske betraktninger omkring fremtidige mulige hendelser, og til å betale prisen. I tillegg vil en stor del av befolkningen, trolig de som trenger det mest, være utestengt fra å etablere uføredekninger på grunn av dårlig helse.

Ut fra dette kan man slutte at hvis målet er å reparere tapet som oppstår ved arbeidsuførhet, så har man lykkes med dette i stadig lavere grad.

\subsection{Har reglene om erstatning ved arbeidsuførhet preventiv virkning?}

Det er skadeserstatningsreglene som er av størst interesse i denne sammenheng. Men også forsikringsavtaler har visse begrensninger i denne retning. Trygderetten har som tidligere nevnt, ikke preventive hensikter i slike tilfeller.

En rekke erstatningsberettigede situasjoner kan dekkes av skadevolders ansvarsforsikring. Man kjøper seg med andre ord fri fra ansvar. Situasjonene som er omfattet, er de uaktsomme hendelsene under culpaansvaret og alle situasjoner under det objektive ansvaret. Når man i tillegg kan se bort fra hendelige uhell som ikke er erstatningspliktige etter culpaansvaret, er det nærmest bare ansvar som følge av forsettelige handlinger som alltid faller på skadevolders skuldre.

Ansvaret reduseres også som følge av at trygdeytelser, og enkelte av skadelidtes forsikringsytelser kommer til fradrag i erstatningsutmålingen.

Det synes klart at slike ansvarsoverføringer begrenser erstatningsreglenes preventive funksjon. 


\subsection{Hvem betaler kostnadene ved tap som følge av arbeidsuførhet?}

Det tredje hensyn som reglene søker å ivareta, er å oppnå best mulig fordeling av kostnadene ved kompensasjon som følge av arbeidsuførhet. Alle tre rettsområder har slike funksjoner.

Prinsippet bak forsikring er nettopp bygget på tanken om pulverisering av tap ved skade. De få som blir utsatt for skade, får dette dekket av de mange som er med i forsikringsfellesskapet. Internt i et forsikringsfellesskap vil det være regler om hvor mye den enkelte skal bidra med i forhold til den risiko man skaper. I hovedtrekk er det likevel slik at de som har god helse eller opptrer forsiktig, er med å betale tapet for dem som har dårligere helse og opptrer mindre forsiktig eller er uheldige.

Trygdeytelsene finansieres av skatter og avgifter fra ansatte, arbeidsgivere og selvstendige næringsdrivende, samt tilskudd fra staten. På samme måte som i forsikringsfellesskapet, men i større grad, blir kostnadene fordelt på hele samfunnet.

Skadeserstatningsytelsene har en annen finansieringsprofil. Kostnadene ved arbeidsuførhet faller i første omgang på den skadelidte. I en del tilfeller skyves imidlertid kostnaden over på en skadevolder, som enten er ansvarlig på culpagrunnlag eller er nærmest til å bære ansvaret og dermed kostnaden (på objektivt grunnlag). Indirekte vil likevel store deler av denne kostnaden betales av deler av samfunnet gjennom forsikringsdekninger. Potensielle skadevoldere vil etablere ansvarsforsikringer og potensielle skadelidte vil etablere personforsikringer. På denne måten pulveriseres kostnadene også her.

Det kan oppsummeres slik: En del av tapet som oppstår ved arbeidsuførhet finansieres alltid delvis av samfunnet via folketrygden. Resten av tapet dekkes i første omgang enten av skadevolder eller skadelidte. Begge parter har imidlertid mulighet, og noen ganger plikt, til å etablere forsikring og dermed overføre sin del av ansvaret på gruppen som forsikringsfellesskapet består av.

Sammen fører reglene på de tre rettsområdene til at tap som følge av arbeidsuførhet i stor grad fordeles på større grupper. Hvis reglene har som formål å fordele tapet på hele eller deler av samfunnet, så har man i stor grad lykkes med det. 


\subsection{Er det mulig å oppnå rettferdighet og rimelighet?}

De fleste har trolig en oppfatning av hva som er rettferdig og rimelig. Det er imidlertid slik at befolkningens oppfatninger varierer strekt. Den enkeltes meninger vil trolig være farget av egen livssituasjon, erfaringer og politiske ståsted. Det er all grunn til å tro at dette også gjelder for spørsmål om kompensasjon ved arbeidsuførhet. Det vil trolig også være slik at oppfatninger av hva som er rettferdig og rimelig endres over tid.

Siden slike betraktninger er betinget av subjektive oppfatninger vil det følgelig ikke være mulig å oppfylle dette hensynet fullt ut. Det nærmeste som man kommer en løsning, er å etablere en rettferdighets- og rimelighetsstandard. Denne standarden må utvikles over tid. Problemet vil imidlertid være at det er vanskelig komme til enighet om en slik standard. Den naturlige følge vil da være at standardene varierer fra gang til gang, avhengig av hvilke politiske kompromissløsninger som kommer i stand. Med dette utgangspunkt ser man konturene av en mulig forklaring på at kompensasjon ved arbeidsuførhet varierer med årsak, ansvar og andre omstendigheter.

\subsection{Sammenfatning}

Det vil være vanskelig eller umulig å etablere et system som ivaretar alle de omtalte hensyn fullt ut. Av drøftelsene over kommer det imidlertid frem at man kunne ivaretatt reparasjonshensynet i større grad enn man gjør. Jeg tenker da spesielt på at erstatningsmulighetene varierer med hva slags situasjon arbeidsuførheten har sin opprinnelse fra. Tapet er jo like stort for den uføre uavhengig av opprinnelsen.

Det er derfor spesielt erstatningsretten som fører til at de totale ytelser varierer. Man kan altså ved å utvikle skadeserstatningsretten, i stor grad oppnå å få utjevnet forskjellene fra område til område. Dette kan for det første gjøres ved å utvide det objektive ansvar samtidig som man gjør det obligatorisk med ansvarsforsikring av "no-fault"-typen. For det andre kan folketrygden utvides til å yte full kompensasjon. På denne måten kan man, om man ønsker det, flytte et tap fra den arbeidsuføre og over på hele eller deler av samfunnet.

En omlegging av erstatningsretten eller trygderetten som skissert over, vil føre til kraftig økte kostnader. Kostnaden vil enten bli fordelt på forsikringstakerene innen samme bransje, eller på de som bidrar til å finansiere folketrygden. 


\section{Avslutning}

Denne avhandlingen søker å belyse fire hovedproblemstillinger. For det første søkes det å avklare hvilke ytelser som er aktuelle ved kompensasjon for inntektsbortfall som følge av arbeidsuførhet. For det andre søkes det belyst hvor stor betydning livsområdet hendelsen som arbeidsuførheten er en følge av, har for slik kompensasjon. For det tredje behandles spørsmålet om hvordan den enkelte ytelse påvirkes av andre ytelser og øvrige omstendigheter. For det fjerde søkes det belyst hvilke hensyn rettsreglene for kompensasjon ved arbeidsuførhet bygger på, samt i hvor stor grad disse hensyn ivaretas.

I det følgende oppsummeres fremstillingen i de foregående kapitler.

Den første problemstillingen besvares under behandlingen av bakgrunnsretten i kapittel 2. Her oppsummeres fremstillingen i 19 tabeller, ett for hvert kompensasjonsgrunnlag for som en arbeidsufør kan gjøre gjeldende. Grunnlagene har sin tilhørighet fra både skadeserstatnings-, trygde- og forsikringsretten. Det finnes flest grunnlag som har bakgrunn fra skadeserstatningsretten.

Når det gjelder problemstilling nr. 2, finner jeg for det første at den uføres kompensasjonsmuligheter i stor grad avhenger av den sammenheng arbeidsuførheten har sin opprinnelse fra. Det vil derfor ofte kunne fremstå som tilfeldig hvilke erstatningsgrunnlag som kan gjøres gjeldende. Ved å betrakte de tre erstatningsområdene skadeserstatning, trygd og forsikring samtidig, får man en sammenheng som vist i figur 12.

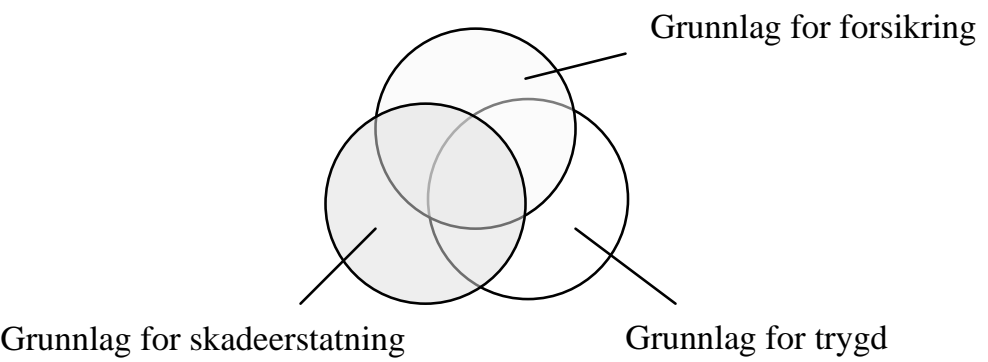

Figur 15: Erstatningsområdene i sammenheng 
Enhver situasjon hvor arbeidsuførhet inntreffer, vil kunne være erstatningsmessig dekket av ett, to, tre eller ingen av disse områdene. Hvor mange av områdene som vil bidra, og hvilke grunnlag som kommer til anvendelse, vil variere fra situasjon til situasjon.

For det andre er det vist at det også er av betydning for den skadelidte hvor ansvaret for hendelsen som førte til arbeidsuførheten, kan plasseres. Det vil være best dekningsgrunnlag dersom ansvaret kan plasseres på andre.

For det tredje er det vist at utmåling av ytelser varierer mellom de forskjellige grunnlag for kompensasjon. Det vil derfor også av denne grunn ha betydning hvilket livsområde arbeidsuførheten har sin opprinnelse fra.

Når det gjelder den tredje problemstillingen, og omstendigheter som påvirker ytelsene, er det vist at samordning har liten praktisk betydning for den arbeidsuføre. Det er mest overkompensasjon som samordnes bort.

Skatt får betydning for de fleste kompensasjonsytelser. Dette blir imidlertid hensyntatt i skadeserstatningsberegningen, og kan hensyntas ved fastsettelse av forsikringssummer. Trygdeytelser vil bli redusert.

Hvilken sikkerhet den skadelidte har for sitt krav, kan få stor betydning. Hvis den som skal yte ikke er betalingsdyktig, vil dette kunne føre til at en ellers berettiget ytelse bortfaller eller blir redusert.

Regler om reduksjon og bortfall kan også få stor betydning. En rekke rettsregler og avtalemessige begrensninger kan føre til at ytelsen blir begrenset. Dette er imidlertid i større grad innenfor den enkeltes kontrollsfære.

Den fjerde hovedproblemstillingen reiser spørsmål om hvilke hensyn reglene skal ivareta. Reparasjonshensynet, prevensjonshensynet, pulveriseringshensynet og rettferdighets- og rimelighetsbetraktninger er identifisert.

Det er videre vist en tendens til at rettsreglene gradvis har fått sin reparasjonsevne redusert. Det er også mulig at ytelser som er beregnet til reparasjon, ikke blir benyttet til reparasjon 
Videre er det vist at reglene på dette området har begrenset preventiv virkning. Det er en følge av at kostnadene pulveriseres gjennom forsikring.

Det er også vist at kostnaden ved å kompensere tap som følge av arbeidsuførhet i stor grad fordeles på hele eller deler av samfunnet. Dette skjer gjennom folketrygdens finansieringsprofil og gjennom forsikring. 


\section{Litteraturliste}

Andresen, Ole (1990): Bilansvaret. Oslo: Tano.

Finansdepartementet (2004): Skattesatser og beløpsgrenser mv. for 2004. http://www.odin.no/fin (20.10.04)

Holgersen, Gudrun og Nils Nygaard (1998): Trygderettslige emner. Bergen.

Kjønstad, Asbjørn (1977): Trygd og erstatning ved personskade. Oslo: Universitetsforlaget.

Kjønstad, Asbjørn (1979): Yrkesskadetrygden. Oslo: Universitetsforlaget.

Kjønstad, Asbjørn (1992): Folketrygdens uførepensjon. Oslo: Universitetsforlaget.

Kjønstad, Asbjørn (1998): Innføring i trygderett, 3. utg. Oslo: Tano.

Kjønstad, Asbjørn (2003): Erstatningsretten i utvikling. Oslo: Universitetsforlaget.

Lilleholt, Kåre (red.)(1998): Knophs oversikt over Norges rett (11. utg). Oslo:

Universitetsforlaget.

Lødrup, Peter (1983): Erstatningsberegningen ved personskader. Oslo.

Lødrup, Peter (1999): Larebok i erstatningsrett. Oslo.

Nygård, Nils (2000): Skade og ansvar. Oslo: Universitetsforlaget.

Norges Forsikringsforbund (1995): Håndbok i forsikring. Oslo: A/S Forsikringslitteratur.

Selmer, Knut S. (1982): Forsikringsrett. Oslo: Universitetsforlaget.

Skårberg, Lars Olav og Marianne Reusch (2003): Yrkesskade. Oslo: Cappelen.

Statistisk Sentralbyrå (2004): Livs- og skadeforsikringsselskaper 2004. http://www.ssb.no (06.08.04)

Trygdeetaten (2004): Trygdeetatens årbok 2003. http://www.trygdeetaten.no (14.09.04)

Tømmerås, Ane Sofie (2002): Billighetserstatning - og andre offentlige erstatningsordninger. Oslo: Universitetsforlaget. 